\title{
S1 Map of the Roman Empire
}

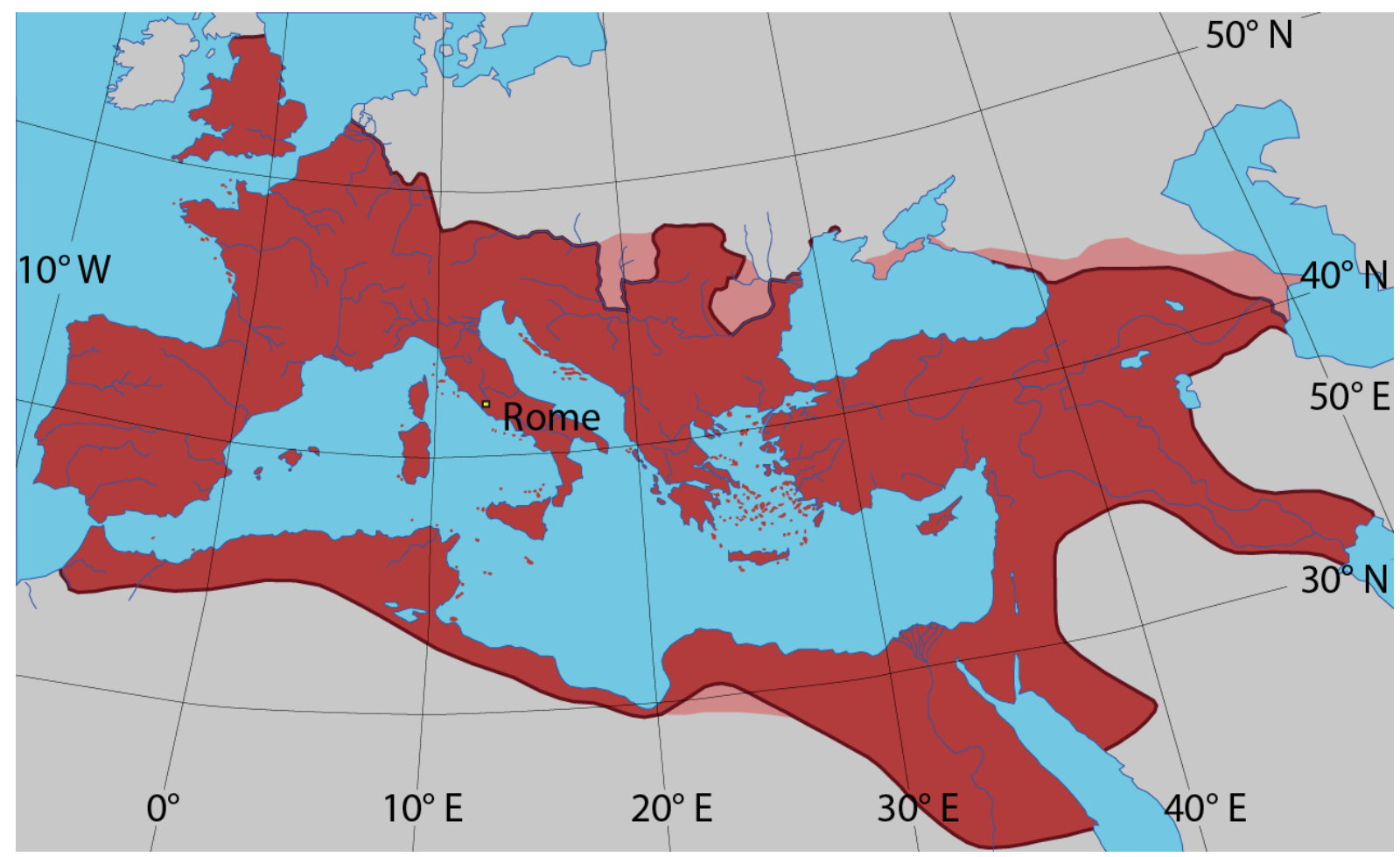

Fig. S1: The Roman Empire at its greatest extent (AD 117) with its vassals in pink. Adapted from Tataryn (2016); licensed under the Creative Commons Attribution-Share Alike 3.0 Unported license (https://creativecommons.org/licenses/by-sa/3.0/deed.en). 


\section{S2 Model set-up}
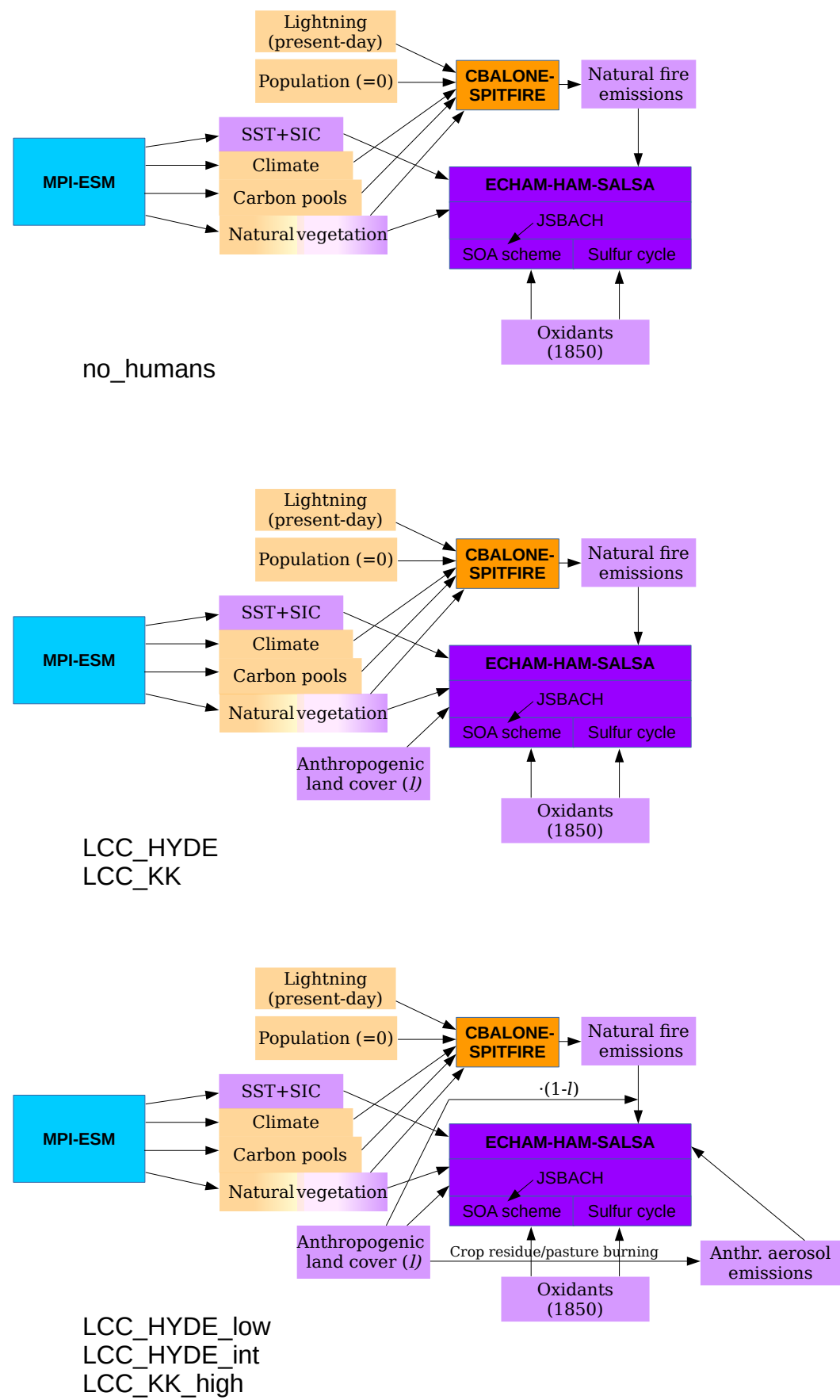

Fig. S2: Illustrated are the setups of the 6 simulations conducted with ECHAM-HAM-SALSA (no_humans, LCC_HYDE, LCC_KK, LCC_HYDE_low, LCC_HYDE_int, and LCC_KK_high). Models that we used are shown in dark colours, whereas inputs to these models are shown in light colours. ECHAM-HAM-SALSA (violet) includes (among other components) the vegetation model JSBACH, a secondary organic aerosol scheme, and a sulfur cycle. Natural fire emissions were calculated with CBALONE-SPITFIRE (orange). For driving the two models, output from the Earth System Model MPI-ESM was used (blue; simulations come from the study by Bader et al., 2019, in review) among others. 
Tab. S1: Greenhouse gas concentrations and orbital parameters. Precession is expressed as the longitude of the perihelion with respect to the equinox. The values are averages over AD 50 to 150 .

\begin{tabular}{l|l|c}
\hline Var. & Unit & Value \\
\hline $\mathrm{CO}_{2}$ & ppm & 278 \\
$\mathrm{CH}_{4}$ & $\mathrm{ppb}$ & 662 \\
$\mathrm{~N}_{2} \mathrm{O}$ & $\mathrm{ppb}$ & 267 \\
Eccentricity & - & 0.01742 \\
Precession & degree & 250.8 \\
Obliquity & degree & 23.68 \\
\hline
\end{tabular}

Tab. S2: Overview of some aerosol emissions in the different ECHAM-HAM-SALSA simulations. The multiplication factor refers to the natural fire emissions calculated with CBALONE-SPITFIRE. $l$ stands for the fraction of the vegetated area that is covered by anthropogenic land (crop and pasture) and AA for anthropogenic aerosol emissions.

\begin{tabular}{l|l|l|l}
\hline Simulation & $\begin{array}{l}\text { Multiplication } \\
\text { factor }\end{array}$ & AA & SOA precursor emissions \\
\hline no_human & 1 & No & based only on natural land cover \\
LCC_HYDE & 1 & No & changed due to anthropogenic land cover \\
cCC_KK & 1 & No & changed due to anthropogenic land cover \\
LCC_HYDE_low & $(1-l)$ & Yes & changed due to anthropogenic land cover \\
LCC_HYDE_int & $(1-l)$ & Yes & changed due to anthropogenic land cover \\
LCC_KK_high & $(1-l)$ & Yes & changed due to anthropogenic land cover \\
\hline
\end{tabular}

\section{S3 Aerosol emissions from fires}

CBALONE-SPITFIRE needs forcing data related to the vegetation and the atmosphere at a daily time resolution as well as a starting point for the carbon pools. To drive CBALONESPITFIRE we used data from MPI_no_LCC (illustrated in Fig. S2) from which output at a high temporal resolution was saved for some selected 30-year periods. The driving data for the AD 100 CBALONE-SPITFIRE simulations represents a slightly earlier period (around AD 1). However, we do not expect a significant difference between AD 1 and AD 100 since the forcing in MPI_no_LCC is very similar for the two years. The 30-year period around AD 1 was repeatedly used to drive both the spin-up $(\approx 100$ years $)$ and the analysed simulated period of CBALONE-SPITFIRE. In the following, we will refer to these fire emissions that are technically for $\mathrm{AD} 1$ as those of $\mathrm{AD} 100$ for simplicity. The emissions have a daily resolution and show interannual variability.

We also calculated fire emissions around AD 1835 (not shown). These emissions were not used as input for our ECHAM-HAM-SALSA simulations listed in Table S2 but for comparison with the fire emissions from van Marle et al. (2017, Sect. S13). We again used high time resolution output from an MPI-ESM simulation to drive CBALONE-SPITFIRE, called MPI_LCC in the following. The only difference between MPI_no_LCC and MPI_LCC is that the latter considers anthropogenic land cover change.

Next to carbon pools and variables related to the vegetation or the atmosphere, the fire model depends on the following additional inputs: i) lightning; ii) population density, together with a regionally varying anthropogenic influence factor $a_{n}$.

To estimate the lightning frequency, we tested the parameterisation by Magi (2015) that is 
based on convective precipitation fluxes. We found that the such-derived lightning frequency is very similar for $\mathrm{AD} 100$ and $\mathrm{AD}$ 1835. However, the simulated lightning frequency differs from the standard lighting frequency used by the MPI-ESM implementation of SPITFIRE (e.g. different spatial pattern; not shown), which is based on the Lightning Imaging Sensor/Optical Transient Detector (LIS/OTD) as described in Lasslop et al. (2014). The difference between the simulated and observation-based lightning frequency is probably associated with the high uncertainties in the parameterised convection scheme. Furthermore, the parameterisation by Magi (2015) works better for convective mass flux through the 0.44 hybrid-sigma pressure level than for convective precipitation, but the former was not available from the MPI-ESM simulations. Thus, we decided to use the observationally derived lightning frequencies by LIS/OTD for both $\mathrm{AD} 100$ and AD 1835 (Fig. S2) in order to not introduce a large bias in natural fire ignitions.

Humans impact fires directly by ignitions and fire fighting as well as indirectly, e.g. by forest management and landscape fragmentation (Arora and Melton, 2018). It is very likely that the relationship between humans and fires has changed in the past centuries and millennia as a consequence of large cultural and political changes. This is neglected in SPITFIRE since $a_{n}$ does not change over time. Instead, $a_{n}$ (and thus the number of anthropogenic ignitions) in SPITFIRE is tuned towards present-day fires where satellite data is available.

For estimating the fire emissions in AD 1835, we nevertheless used CBALONE-SPITFIRE with the present-day dependence on population density (i.e. the standard $a_{n}$ ), as it was done by the FIREMIP project for calculating fire emissions from 1750 to today (Rabin et al., 2017). For these CBALONE-SPITFIRE simulations, we averaged the population density from HYDE11 over 1830 and 1840. Furthermore, we considered anthropogenic land cover change when calculating the fire emissions; the same changes were used as in MPI_LCC.

For AD 100, we used CBALONE-SPITFIRE to calculate natural fire emissions (Fig. S2), assuming no anthropogenic influence. Hence, no anthropogenic land cover change was considered in these CBALONE-SPITIRE simulations. Furthermore, the population density was set to 0 and $a_{n}$ thus becomes irrelevant. The ECHAM-HAM-SALSA simulations LCC_HYDE_low, LCC_HYDE_int, and LCC_KK_high account for anthropogenic aerosol emissions, which include agricultural burning. Using the same natural fire emissions in these simulations than in the other simulations (no_human, LCC_HYDE, and LCC_KK) would lead to an overestimation in total aerosol emissions since natural aerosol emissions should not occur where now crop or pasture grows. Therefore, we reduced the natural fire emissions of the simulations LCC_HYDE_low, LCC_HYDE_int, and LCC_KK_high offline to account for regions subject to anthropogenic land use (Table S2 Fig. S2). As a first order approximation, the natural fires calculated with CBALONE-SPITFIRE were multiplied with $(1-l)$, where $l$ is the fraction of the vegetated area per gridbox that is covered by crop and pasture.

\section{S4 Aerosol emission factors for fuel consumption}

The fuel consumption studies that we considered mostly provide emission factors for either open fire places or traditional stoves. An exception is the measurement of olive pits that we included, which was conducted in a pellet stove; it was the only measurement of olive pits that we could find, and olive oil pressing waste was employed as a domestic and industrial fuel throughout Antiquity in the Mediterranean (Rowan, 2015). 


\section{S4.1 Wood}

For wood combustion, we considered many wood types which were abundant in the Roman Empire (e.g. different types of oak, olive tree, maritime pine, or beech). However, many of these measurements were conducted with the same burning devices (Alves et al., 2011; Calvo et al., 2015 Fernandes et al., 2011). Looking at different studies, we observed that the differences in $E F$ s between different wood types are sometimes smaller than the differences between different measurement setups. Hence, we also decided to include some trees in our compilation which were not present in the Mediterranean region (e.g. Lespedeza, Paulownia) to consider more independent studies. The medians and quartiles that were derived for the emission factors of wood $\left(E F_{\text {wood }}\right)$ from the random sampling can be found in Table S3.

\section{S4.2 Agricultural waste}

For agricultural waste, a large variety of burning material was considered (e.g. wheat straw, rice straw, dung). Although the composition of agricultural residues in the Roman Empire differs from our compilation (e.g. rather Triticum dicoccum and barley instead of Triticum aestivum and rice; olive pits and chickpeas instead of peanuts and soybean residues), we assume that the emission factors are not fundamentally different: our compilation considers a large range of agricultural waste types. Furthermore, based on our compiled data, the measurement setup seems to be as important as the specific fuel type. The calculated medians and quartiles for the emission factors of agricultural waste $\left(E F_{\text {agri }}\right)$ can be found in Table $\mathrm{S} 4$.

\section{S4.3 Charcoal}

Compared to wood and agricultural waste, only few studies estimated aerosol EFs for charcoal burning and charcoal making. Furthermore, most of them provide measurements of total suspended particles (e.g. Smith, 2000), and not for BC and OC. Thus, we considered only the very recent study by Keita et al. (2018) for BC and OC, who measured BC and OC for charcoal cooking fires and charcoal making in West Africa and calculated emission factors. Maybe even more important than knowing the exact $\mathrm{BC}$ and $\mathrm{OC}$ emission factors for charcoal burning is considering also the emissions from charcoal making. To produce $1 \mathrm{~kg}$ of charcoal, approximately $7 \mathrm{~kg}$ of wood are needed with traditional methods (Olson, 1991). As a consequence, using charcoal instead of wood as fuel might overall result in similar or even higher aerosol emissions, since for every kilogramme of charcoal burnt, the aerosols emitted during the production of this kilogramme of charcoal should also be considered. The aerosol emission factors per kilogramme of wood used for charcoal $\left(E F_{\mathrm{ch}_{\mathrm{w}}}\right)$ were therefore calculated as:

$$
E F_{\mathrm{ch}_{\mathrm{w}}}=\frac{1}{7} \cdot E F_{\mathrm{chb}}+E F_{\mathrm{chm}},
$$

where $E F_{\text {chb }}$ is the emission factor for charcoal burning (per kilogramme of charcoal) and $E F_{\text {chm }}$ is the emission factor for charcoal making (per kilogramme of wood). The emission factors for $E F_{\text {chb }}$ and $E F_{\text {chm }}$ can be found in Tables $\mathrm{S} 5$ and $\mathrm{S} 6$, respectively.

Considering that charcoal is often cited as almost smokeless (e.g. Wood and Baldwin, 1985 Lohri et al., 2016), the measured $E F_{\text {chb }}$ of BC (median: $0.59 \mathrm{~g} \mathrm{~kg}^{-1}$; comparable to the burning of other types of biofuel) is relatively high - a discrepancy that already Bond et al. (2004) noted for the emission factors of total suspended particles. In the future, more measurements could help to better understand this inconsistency. 
Inserting the estimates of $E F_{\text {chb }}$ and $E F_{\text {chm }}$ in the equation above results in $E F_{\mathrm{ch}_{\mathrm{w}}}$ of $0.26 \mathrm{~g} \mathrm{~kg}_{\text {wood }}^{-1}(0.18,0.39)$ for $\mathrm{BC}, 3.94 \mathrm{~g} \mathrm{~kg}_{\text {wood }}^{-1}(3.27,4.80)$ for $\mathrm{OC}$, and $0.21 \mathrm{~g} \mathrm{~kg}_{\text {wood }}^{-1}(0.14$, 0.32 ) for $\mathrm{SO}_{2}$.

\section{S4.4 Combining different sectors}

To assess the overall emission factor, we needed to estimate how much which sector contributed to the total fuel consumption. Except for $\mathrm{SO}_{2}$, the emission factors are similar for wood and agricultural waste. The OC emission factors for charcoal burning and production (expressed as per kilogramme wood) are larger than for wood and agricultural waste, whereas the opposite is the case for BC. Thus, different assumptions concerning the contributions from the three sectors would affect the $\mathrm{BC}$ to $\mathrm{OC}$ ratio, rather than the overall emissions of both of them.

Wood fuel (including wood for charcoal making) was the dominant fuel in the Roman Empire (Olson, 1991). However, agricultural residues such as chaff, olive pits, and dung were also used, most evidently in regions lacking in supplies of wood (e.g. Roman North Africa and Roman East; Mietz, 2016 Rowan, 2015). In developing countries in 1985, the mass contribution of agricultural waste to total biofuel combustion (excluding burning in fields) ranges from $14 \%$ in Africa to over $40 \%$ in Asia (Yevich and Logan, 2003). Based on these numbers, we assumed that $20 \%$ of the used fuel consisted of agricultural waste.

Like for developing countries (Wood and Baldwin, 1985 Yevich and Logan, 2003 Lohri et al., 2016), the use of charcoal was especially important in urban areas in ancient times (Veal, 2017). Veal (2017) assumes that in the cities "perhaps 80\%" of the burnt fuel consisted of charcoal with the remainder being wood, whereas the opposite ratio occurred in rural areas. In her two extreme case scenarios for Rome, she used charcoal contributions of $80 \%$ and $20 \%$ to total fuel. Assuming a conversion factor of 7 , this means that $97 \%$ and $64 \%$ of the wood fuel was used for charcoal making, respectively.

These estimates are higher than present-day estimates in countries where charcoal is produced: using data from the food and agricultural organisation $\left(\mathrm{FAO}^{1}\right)$, we calculated the contribution of charcoal production to total wood fuel production. We chose the year 1970, when fossil fuels were likely (even) less common in developing countries than today. A factor of 6 was used $^{2}$ to convert the weight of charcoal (metric tonnes) to the volume of wood $\left(\mathrm{m}^{3}\right)$ required to make the specified charcoal weight. It is unclear whether countries include the amount of wood used for charcoal making in the woodfuel statistics which they report to $\mathrm{FAO}^{3}$. To account for the fact that the data might be inconsistent, we used two methods (DIV1 and DIV2) to calculate the contribution of charcoal to wood fuel ( $f_{r a c_{\text {DIV1 }}}$ and $\left.f r a c_{\text {DIV2 }}\right)$ :

$$
\operatorname{frac}_{\mathrm{DIV} 1}=\frac{\text { Wood }_{\mathrm{ch}}}{\text { Wood }_{\mathrm{con}}+\text { Wood }_{\mathrm{noncon}}}
$$

and

$$
\operatorname{frac}_{\mathrm{DIV} 2}=\frac{\operatorname{Wood}_{\mathrm{ch}}}{\operatorname{Wood}_{\mathrm{ch}}+\operatorname{Wood}_{\mathrm{con}}+\operatorname{Wood}_{\mathrm{noncon}}},
$$

where $\operatorname{Wood}_{\mathrm{ch}}$ stands for the production of wood used for charcoal making, Wood $_{\text {con }}$ for the production of coniferous fuel wood, and $\operatorname{Wood}_{\text {noncon }}$ for the production of non-coniferous fuel wood. With method DIV1, we arrive at values above $100 \%$ for some countries. Since this makes

\footnotetext{
1 http://www.fao.org/faostat/en/\#data/F0, downloaded: 18 August 2018

2 http://www.fao.org/docrep/005/y4450e/y4450e13.htm, last access: 27 November 2018; a similar value of 7 is mentioned here: http://www.fao.org/docrep/x5667e/x5667e04.htm, last access: 17 Januar 2019

${ }^{3}$ http://www.fao.org/docrep/005/y4450e/y4450e13.htm
} 
no sense, we cap these values at $100 \%$.

We calculated the mean and the median fractions for both the world and Africa, the latter having the largest per capita use of charcoal in the developing world (Yevich and Logan, 2003). For both cases, we excluded all countries that do not produce charcoal, i.e. mainly developed countries that predominantly use fossil fuels. The values are shown in Table S7. The values lie in a relatively narrow range between $13 \%$ and $25 \%$. Although the large majority of people living in developing countries mainly used biomass for domestic energy (Wood and Baldwin, 1985), it is possible that the use of fossil fuels might affect our estimates to some degree.

Overall, the FAO data shows lower contributions of charcoal to total fuel wood than the estimates by Veal (2017). This could indicate that the estimates by Veal (2017) are too high for the whole Roman Empire (which was not the target of her study), since the Empire consisted of many parts that differed considerably with respect to wood supply. However, the Roman Empire had a high urbanisation rate $(\approx 10 \%$, with higher values in Italy; Temin, 2006) and metallurgy was important (Harris, 2013), which speakes for a potentially higher contribution of charcoal than under present-day conditions. In the end, we decided to use a fraction of $50 \%$ of charcoal wood to total fuel wood, which is a compromise between the estimates by Veal (2017) and the FAO based values. To summarise, we assume that $20 \%$ of the fuel consisted of agricultural waste, $40 \%$ of charcoal (in terms of wood needed for charcoal production), and $40 \%$ of wood.

Tab. S3: Aerosol emission factors for wood burning ( $\left.E F_{\text {wood }}\right)$ in $\mathrm{g} \mathrm{kg}^{-1}$ used for the low, the intermediate, and the high scenarios.

\begin{tabular}{c|c|r|r}
\hline & Low estimate & Intermediate estimate & High estimate \\
\hline $\mathrm{BC}$ & 0.27 & 0.42 & 0.65 \\
$\mathrm{OC}$ & 0.84 & 2.09 & 4.15 \\
$\mathrm{SO}_{2}$ & 0.0021 & 0.098 & 0.20 \\
\hline
\end{tabular}

Tab. S4: Aerosol emission factors for agricultural waste burning (as fuel; $E F_{\text {agri }}$ ) in $\mathrm{g} \mathrm{kg}^{-1}$ used for the low, the intermediate, and the high scenarios.

\begin{tabular}{c|c|c|c}
\hline & Low estimate & Intermediate estimate & High estimate \\
\hline $\mathrm{BC}$ & 0.25 & 0.45 & 0.85 \\
$\mathrm{OC}$ & 1.16 & 2.40 & 4.32 \\
$\mathrm{SO}_{2}$ & 0.0082 & 0.022 & 0.050 \\
\hline
\end{tabular}

Tab. S5: Aerosol emission factors for charcoal burning $\left(E F_{\text {chb }}\right)$ in $\mathrm{g} \mathrm{kg}^{-1}$ (per kg charcoal) used for the low, the intermediate, and the high scenarios.

\begin{tabular}{c|r|r|r}
\hline & Low estimate & Intermediate estimate & High estimate \\
\hline $\mathrm{BC}$ & 0.44 & 0.59 & 0.79 \\
$\mathrm{OC}$ & 0.45 & 0.96 & 2.03 \\
$\mathrm{SO}_{2}$ & 0.29 & 0.43 & 0.62 \\
\hline
\end{tabular}


Tab. S6: Aerosol emission factors for charcoal production $\left(E F_{\text {chm }}\right)$ in $\mathrm{g} \mathrm{kg}^{-1}$ (per $\mathrm{kg}$ wood) used for the low, the intermediate, and the high scenarios.

\begin{tabular}{c|r|r|r}
\hline & Low estimate & Intermediate estimate & High estimate \\
\hline $\mathrm{BC}$ & 0.11 & 0.18 & 0.28 \\
$\mathrm{OC}$ & 3.21 & 3.81 & 4.51 \\
$\mathrm{SO}_{2}$ & 0.10 & 0.15 & 0.23 \\
\hline
\end{tabular}

Tab. S7: The percentages of wood used for charcoal making to total fuel wood. Two different methods (DIV1 and DIV2) were applied. Data was taken from FAO (year 1970).

\begin{tabular}{l|r|r|r|r}
\hline Method & World, mean & World, median & Africa, mean & Africa, median \\
\hline frac $_{\text {DIV1 }}$ & $25 \%$ & $16 \%$ & $24 \%$ & $16 \%$ \\
frac $_{\text {DIV2 }}$ & $18 \%$ & $13 \%$ & $18 \%$ & $14 \%$ \\
\hline
\end{tabular}

\section{S5 Estimating crop yield $Y$}

The agronomist Columella stated that the seed-yield ratios for most parts of Italy were seldom above 4:1 in the first century AD (Spurr, 1986). Assuming a sowing amount of $135 \mathrm{~kg} \mathrm{ha}^{-1}$ (advocated by the agronomists as a typical sowing amount; Goodchild, 2007), a ratio of 4:1 results in yields of $540 \mathrm{~kg} \mathrm{ha}^{-1}$. This yield is quite low compared to other sources, which show that yields of 5:1 and 6:1 were the most frequent in Italy and higher yields of 10-15:1 were not infrequent (Goodchild, 2007). For some regions, Varro (who lived in the first century BC) and Pliny the Elder (first century AD) reported even yields of 100:1 (Sinclair, 1998). So far, the estimates referred to Italy alone, but the variability between different Mediterranean countries was of course large: around AD 1921-1930 the average yields according to Hopkins (2017) ranged from values below $600 \mathrm{~kg} \mathrm{ha}^{-1}$ (Cyrenaica, Tunisia, Algeria), through values between 600 and $1000 \mathrm{~kg} \mathrm{ha}^{-1}$ (Greece, Portugal, Cyprus, Syria and Lebanon, Turkey, Spain) up to values above $1000 \mathrm{~kg} \mathrm{ha}^{-1}$ (Bulgaria, Yugoslavia, Italy, France, Egypt). Overall, we concluded that yields representative for the whole Roman Empire roughly lie in the range between $500 \mathrm{~kg} \mathrm{ha}^{-1}$ and $1000 \mathrm{~kg} \mathrm{ha}^{-1}$.

\section{S6 Estimating $\operatorname{Fr}_{\text {crop burnt }}$}

There are several options for what happened after harvest with the remaining residue on the field: when chaff was short, straw could be used as livestock feed (Spurr, 1986) or the residues left could be directly grazed by ruminants (Spurr, 1986), as it happens also nowadays e.g. in Mediterranean North Africa (Yevich and Logan, 2003). However, Spurr (1986) states that animals rarely eat stubble but rather the edible weeds and grass which grow among it. Farmers that had no further use for the stubble left after harvesting burnt it (Spurr, 1986). In ancient sources, burning was mentioned as method to destroy weeds or to fertilise the soil (Spurr, 1986). Spurr (1986) assumed that especially small farmers who could not store straw and had few animals to feed would burn the stubble.

Nowadays, crop residue burning is not widespread in developed countries anymore, and many countries in western Europe even forbid open field burning (Yevich and Logan, 2003). To have a rough indication for how much of the remaining residue might have been burnt in the Roman Empire, we used present-day estimates from developing countries as an indication (also countries that cultivate rice despite the fact that rice was not grown in the Roman Empire). Yevich and Logan (2003) found that in 1985 of the available residue, 1\%, 23\%, and $38 \%$ was burnt in the 
fields in China, in India, and in the rest of Asia, respectively. Note that a more recent estimate for crop residue burning in China arrives at much higher fractions than the study by Yevich and Logan (2003): based on satellite data, Li et al. (2016a) find that $23 \%$ of the field area is burnt. A large part of the discrepancy can be explained by the different year: Yevich and Logan (2003) derive estimates for 1985, whereas Li et al. (2016a) analyse the year 2012. Field surveys from China show that the proportion of residue that is burnt is larger when the crops are harvested by a combine harvester compared to manual harvesting (Yang et al., 2008). In line with this, Li et al. (2016b) estimate that the fractions of crop residues burnt in fields increased from $5 \%$ in 1990 to $23 \%$ in 2013. Another reason why crop residue burning has increased might be that the use of biofuels has decreased (Yang et al., 2008). Note that we do not expect that mechanisation leads to enhanced crop residue burning in general; modern-day technology can also be used to prepare fields for the next crop planting after harvest (Pfeiffer et al., 2013), which makes the burning of crop residue unnecessary.

In the Philippines and Indonesia, up to $65 \%$ and $73 \%$ of the residue was burnt in fields in 1985 (Yevich and Logan, 2003). This is similar to the satellite-derived fraction of rice fields under burning for the Punjab region in India in 2015 (66\%, PRSC, 2015); as reasons for the large burning in the Punjab region, highly mechanised farming, poor storage facility for the straw, and lack of market demand for further use are mentioned among others (PRSC, 2015). A survey in Bangladesh shows that only $3 \%$ of the farmers burn the total residue but that $37 \%$ burn the lower part of it (Haider, 2011); the surveyed farmers manually gather the residue from the field.

By the use of $p_{b}$, we have already accounted for the part of residue used as biofuel. If we remove this part of the residue from the estimates above, then the fractions of burning in the field would increase. Based on all the studies that we have mentioned, we estimate that $40 \%$ of the crop area is annually burnt for the simulation LCC_HYDE_int $\left(F r_{\text {crop burnt }}=0.4 \mathrm{y}^{-1}\right)$. For the low and the high scenarios, we changed this fraction by a factor of 2 and arrive at $20 \%$ and $80 \%$, respectively. The $80 \%$ are reached under present-day conditions in the countries with most crop residue burning (e.g. Indonesia). Pfeiffer et al. (2013) use a value of $20 \%$ in their pre-industrial fire model (LPJ-LMfire v1.0) and consider this to be a conservative estimate.

\section{S7 Estimating $F$}

Values of fuel loads ( $\mathrm{kg}_{\text {dry }}$ matter per area) frequently lie in the range between 0.3 and $0.5 \mathrm{~kg} \mathrm{~m}^{-2}$ for pastures and grasslands: for Kentucky Bluegrass, $0.26,0.36$, and $0.64 \mathrm{~kg} \mathrm{~m}^{-2}$ were measured in Idaho (Holder et al., 2017); values for grasslands in Australia are around $0.32 \mathrm{~kg} \mathrm{~m}^{-2}$ and $0.46 \mathrm{~kg} \mathrm{~m}^{-2}$ (Cruz et al., 2016 Cruz et al., 2017); in South Africa, total aboveground fuel loads in savanna parklands range from 0.22 to $0.55 \mathrm{~kg} \mathrm{~m}^{-2}$ (except for a site subjected to 38 years of fire exclusion; Shea et al., 1996), whereas the fuel loads of standing herbaceous material range from 0.30 to $0.41 \mathrm{~kg} \mathrm{~m}^{-2}$ (Smith et al., 2013); a total fuel load of $0.49 \mathrm{~kg} \mathrm{~m}^{-2}$ for Mediterranean grasslands in Greece was measured (Dimitrakopoulos, 2002).

Fuel biomass consumptions for savannas are comparable: $0.26 \mathrm{~kg} \mathrm{~m}^{-2}$ for savanna woodlands for early dry season burns, $0.46 \mathrm{~kg} \mathrm{~m}^{-2}$ for savanna woodlands for mid/late dry season burns, $0.21 \mathrm{~kg} \mathrm{~m}^{-2}$ for savanna grasslands for early dry season burns, and $1.0 \mathrm{~kg} \mathrm{~m}^{-2}$ for savanna grasslands for mid/late dry season burns $\left(0.54 \mathrm{~kg} \mathrm{~m}^{-2}\right.$ when excluding one high value for tropical pasture; Aalde et al., 2006).

Based on these studies, we roughly estimate that the fuel biomass consumption is $F=$ $0.35 \mathrm{~kg}_{\text {dry matter }} \mathrm{m}^{-2}$. 


\section{S8 Estimating $\mathrm{Fr}_{\text {pasture burnt }}$}

In general, the abundance of prescribed burning depends on the accumulation of biomass: the higher the accumulation, the shorter the fire interval is. As a consequence, the fire interval depends on rainfall and grazing pressure (Weir et al., 2013 Frost and Robertson, 1987), thus showing pronounced regional variability.

For phryganic rangelands in Greece, it is recommended to set fire every 3 to 4 years, which allows to have a good herbage production and at the same time to suppress undesirable dwarf shrub (Papanastasis, 1980). In South Africa, Oluwole et al. (2008) found that the recovery period should be 3 years for optimum productivity in the absence of grazing. In line with this, the Burning Guidelines of South Africa do not recommend to burn pasture every year (what some farmers do), but every 2-5 years in mesic and coastal grasslands and only when it is needed in dry highveld grasslands (SANBI, 2014). Smith et al. (2013) found that grass richness, evenness, and diversity was high for sites with high rainfall when frequent burning was applied in the dry season (1- to 3-year return intervals), whereas Little et al. (2015) conclude that annual burning combined with intensive grazing has a detrimental effect on plant species diversity and structure. In Australia, single fires caused a short-term reduction of yield and cover of pastures in the following year, but fast recovery occurred for most burning regimes. However, perennial grasses were reduced on the costs of annual grasses, which is why burning every 5-6 and 4-6 years for arid short grass and ribbon blue grass, respectively, are recommended (Dyer, 2011). This is in agreement with the findings of Norman (1963) and Norman (1969) for native pasture on Tippera clay loam in the Katherine region. For North America, the recommended fire-return-interval of prescribed patch burning is 3 years in areas with rainfall above $\approx 760 \mathrm{~mm}$ per year and 4 years in drier regions (Weir et al., 2013).

One could argue that farmers in the past did not necessarily follow these present-day guidelines. However, traditional knowledge of prescribed burning has been lost in many European areas (Montiel and Kraus, 2010). Guidelines thus partially re-establish knowledge that our ancestors had. On the one hand, if burning every year reduces the productivity of many grasslands, we think that it is unlikely that ancient farmers conducted burning so often. On the other hand, a too long period without burning is also unlikely since this e.g. allows the growth of unwanted species and can have adverse effects on the ecosystem (SANBI, 2014 Papanastasis, 1980 ). According to the summarised literature, burning every $\approx 3$ years seems to be a reasonable intermediate estimate. Therefore, we assumed that $30 \%$ of the pasture area is burnt per year for the intermediate scenario. For the low and the high emission scenarios, we changed this fraction by a factor of 2 and thus arrive at $15 \%$ and $60 \%$, respectively. 


\section{S9 Seasonal impact of anthropogenic land cover change}

Tab. S8: Absolute values of the reference simulation no_human ("no") and the simulation LCC_HYDE ("H") for each season (JJA=summer, $\mathrm{SON}=$ autumn, DJF=winter, and MAM=spring) and the whole year: cloud droplet number concentration burden, liquid water path, cloud cover, cloud radiative effect, precipitation, wind velocity at $10 \mathrm{~m}$ altitude, surface albedo over land, evaporative fraction, turbulent flux, land surface temperature, and $2 \mathrm{~m}$-temperature. The values are averaged from $10^{\circ} \mathrm{W}$ to $50^{\circ} \mathrm{E}$ and from $20^{\circ} \mathrm{N}$ to $60^{\circ} \mathrm{N}$. Changes are shown in brackets (relative except for temperature) and the stars indicate significant changes ( $5 \%$ significance level; $N=20$ ).

\begin{tabular}{|c|c|c|c|c|c|c|c|c|c|c|c|c|}
\hline Var. & Unit & no JJA & H JJA & no SON & & $\mathrm{SON}$ & no DJF & H DJF & no MAM & H MAM & no year & H year \\
\hline CDNC & $10^{9} \mathrm{~m}^{-2}$ & 31.46 & $30.54(-2.9 \%)$ & 27.12 & 25.66 & $(-5.4 \%)$ & 12.85 & $13.19 \quad(2.6 \%)$ & 22.49 & $21.92(-2.5 \%)$ & 23.52 & $22.87(-2.8 \%)$ \\
\hline LWP & $\mathrm{g} \mathrm{m}^{-2}$ & 54.96 & $54.89(-0.1 \%)$ & 59.03 & 56.36 & $(-4.5 \%)$ & 39.22 & $39.1 \quad(-0.3 \%)$ & 41.49 & $40.13(-3.3 \%)$ & 48.69 & $47.64(-2.2 \%)$ \\
\hline $\mathrm{CC}$ & - & 0.32 & $0.31(-3.1 \%)$ & 0.50 & 0.51 & $(2.1 \%)$ & 0.58 & $0.58 \quad(1.2 \%)$ & 0.54 & $0.54(-0.7 \%)$ & 0.48 & $0.48 \quad(0.2 \%)$ \\
\hline CRE & $\mathrm{W} \mathrm{m}^{-2}$ & -22.44 & $-22.58 \quad(0.6 \%)$ & -4.23 & -2.91 & $(-31.1 \%) *$ & 4.57 & $4.6 \quad(0.5 \%)$ & -14.43 & $-14.12(-2.1 \%)$ & -9.21 & $-8.83(-4.1 \%)$ \\
\hline Precipitation & $\mathrm{mm} \mathrm{d}^{-1}$ & 0.83 & $0.81(-1.9 \%)$ & 1.27 & 1.30 & $(2.5 \%)$ & 1.53 & $1.52(-0.5 \%)$ & 1.26 & $1.28 \quad(1.5 \%)$ & 1.22 & $1.23(0.5 \%)$ \\
\hline Wind $_{10}$ & $\mathrm{~m} \mathrm{~s}^{-1}$ & 4.02 & $4.05 \quad(0.8 \%)$ & 4.09 & 4.14 & $(1.1 \%)$ & 4.63 & $4.66 \quad(0.6 \%)$ & 4.33 & $4.37 \quad(1.1 \%)$ & 4.27 & $4.30 \quad(0.9 \%) *$ \\
\hline Albedo & - & 0.26 & $0.26 \quad(0.2 \%) *$ & 0.25 & 0.25 & $(-0.0 \%)$ & 0.26 & $0.26(-0.3 \%)$ & 0.25 & $0.25(-0.2 \%)$ & 0.26 & $0.26(-0.1 \%)$ \\
\hline Evap_frac & - & 0.36 & $0.36(-1.2 \%)$ & 0.32 & 0.33 & $(0.8 \%)$ & 0.32 & $0.33(3.2 \%) *$ & 0.43 & $0.43 \quad(0.7 \%)$ & 0.36 & $0.36 \quad(0.8 \%)$ \\
\hline $\mathrm{F}_{\text {turb }}$ & $\mathrm{W} \mathrm{m}^{-2}$ & 90.23 & $89.66(-0.6 \%)$ & 64.62 & 64.80 & $(0.3 \%)$ & 52.26 & $52.73 \quad(0.9 \%)$ & 79.54 & $(0.5 \%)$ & 71.78 & $(0.2 \%)$ \\
\hline $\mathrm{T}_{\mathrm{s}}$ & K & 300.29 & $300.28(-0.01)$ & 290.56 & 290.94 & $(0.38) *$ & 279.35 & $279.31(-0.04)$ & 290.17 & 290.25 & 290.14 & 290.25 \\
\hline $\mathrm{T}_{2}$ & $\mathrm{~K}$ & 297.56 & $297.51(-0.05)$ & 289.96 & 290.24 & $(0.28) *$ & 280.18 & $280.14(-0.04)$ & 288.26 & 288.31 & 289.03 & 289.09 \\
\hline
\end{tabular}


Tab. S9: The same as Table $\mathrm{S} 8$ but for the simulations no_human and LCC_KK ("KK").

\begin{tabular}{|c|c|c|c|c|c|c|c|c|c|c|c|}
\hline Var. & Unit & no JJA & KK JJA & no SON & KK SON & no DJF & KK DJF & no MAM & KK MAM & no year & KK year \\
\hline CDNC & $10^{9} \mathrm{~m}^{-2}$ & 31.46 & $29.84(-5.2 \%)$ & 27.12 & $25.51(-5.9 \%) *$ & 12.85 & $11.73(-8.7 \%) *$ & 22.49 & $20.36(-9.5 \%) *$ & 23.52 & $21.90(-6.9 \%) *$ \\
\hline LWP & $\mathrm{g} \mathrm{m}^{-2}$ & 54.96 & $53.48(-2.7 \%)$ & 59.03 & $(-5.2 \%) *$ & 39.22 & $36.07(-8.1 \%) *$ & 41.49 & $37.96(-8.5 \%) *$ & 48.69 & $45.89(-5.8 \%) *$ \\
\hline $\mathrm{CC}$ & - & 0.32 & $0.31(-1.7 \%)$ & 0.50 & $(1.3 \%)$ & 0.58 & $0.58 \quad(0.1 \%)$ & 0.54 & $0.53(-1.5 \%)$ & 0.48 & $0.48(-0.3 \%)$ \\
\hline CRE & $\mathrm{W} \mathrm{m}^{-2}$ & -22.44 & $-22.20(-1.1 \%)$ & -4.23 & $-3.13(-25.8 \%) *$ & 4.57 & $(0.4 \%)$ & -14.43 & $-13.28(-8.0 \%)$ * & -9.21 & $-8.58(-6.8 \%) *$ \\
\hline Precipitation & $\mathrm{mm} \mathrm{d}^{-1}$ & 0.83 & $0.84 \quad(2.1 \%)$ & 1.27 & $1.24 \quad(-2.8 \%)$ & 1.53 & $1.51(-1.2 \%)$ & 1.26 & $1.23(-2.9 \%)$ & 1.22 & $1.20(-1.5 \%)$ \\
\hline Wind $_{10}$ & $\mathrm{~m} \mathrm{~s}^{-1}$ & 4.02 & $(3.9 \%) *$ & 4.09 & $(3.2 \%) *$ & 4.63 & $4.74 \quad(2.4 \%) *$ & 4.33 & $4.49 \quad(3.7 \%)$ * & 4.27 & $4.41 \quad(3.3 \%) *$ \\
\hline Albedo & - & 0.26 & $(0.8 \%) *$ & 0.25 & $(0.2 \%)$ & 0.26 & $(0.0 \%)$ & 0.25 & $0.25(-0.5 \%)$ * & 0.26 & $(0.1 \%)$ \\
\hline Evap_frac & - & 0.36 & $0.36 \quad(1.1 \%)$ & 0.32 & $(1.3 \%)$ & 0.32 & $(3.9 \%) *$ & 0.43 & $0.43 \quad(0.6 \%)$ & 0.36 & $(1.6 \%) *$ \\
\hline $\mathrm{F}_{\text {turb }}$ & $\mathrm{W} \mathrm{m}^{-2}$ & 90.23 & $90.20(-0.0 \%)$ & 64.62 & $(-0.8 \%)$ & 52.26 & $(0.1 \%)$ & 79.54 & $(1.7 \%)$ & 71.78 & $(0.3 \%)$ \\
\hline $\mathrm{T}_{\mathrm{S}}$ & K & 300.29 & $300.43 \quad(0.13)$ & 290.56 & $(0.38) *$ & 279.35 & 279.38 & 290.17 & $290.23 \quad(0.06)$ & 290.14 & $(0.15) *$ \\
\hline $\mathrm{T}_{2}$ & K & 297.56 & $297.51(-0.05)$ & 289.96 & $(0.23) *$ & 280.18 & 280.20 & 288.26 & $288.24(-0.02)$ & 289.03 & 289.08 \\
\hline
\end{tabular}




\section{S10 Comparison of anthropogenic aerosol emissions in AD 100 and AD 1850}

To put our calculated anthropogenic aerosol emissions for AD 100 into some temporal context, we compare them to the anthropogenic aerosol emissions in AD 1850 based on the ACCMIP (Atmospheric Chemistry \& Climate Model Intercomparison Project) inventory (Lamarque et al., 2010). The emissions are in both cases averaged over our study domain and the year. ACCMIP includes the sectors energy production and distribution, industry, land transport, maritime transport, residential and commercial combustion, agricultural waste burning on fields, and waste. Not all of these sectors produced aerosol emissions in AD 100; our emissions thus only include fuel consumption (both due to industrial as well as residential combustion), agricultural waste burning on fields, and pasture burning. The emissions from pasture burning might be part of the class "open vegetation fires in savanna and grasslands" in ACCMIP and are thus not considered in this comparison; we expect that the ACCMIP emissions in AD 1850 could be somewhat higher if pasture burning were included.

The BC emissions from the high scenario in AD 100 are nearly as high as the emissions in $\mathrm{AD}$ 1850, whereas the emissions from the low and the intermediate scenarios are considerably lower (Fig. S3a). For OC, the emissions for the low and the intermediate scenarios are lower than the emissions in AD 1850, whereas the high scenario results in approximately twice as high aerosol emissions as in AD 1850 (Fig. S3b). The large OC emissions in AD 100 could be due to differences in emission factors: uncertainties in emission factors from biomass burning are large, and the composition of fuels was different in AD 1850 than in AD 100 (e.g. more coal in AD 1850). For $\mathrm{SO}_{2}$, the emissions in $\mathrm{AD} 100$ are for all scenarios clearly lower than those in $\mathrm{AD}$ 1850 (Fig. S3a), which might again be related to the larger contribution of fossil fuels in AD 1850.

Comparing the aerosol emissions per capita gives similar results (Fig. S4): relative to AD 1850, emissions are highest in $\mathrm{AD} 100$ for $\mathrm{OC}$, followed by $\mathrm{BC}$ and then $\mathrm{SO}_{2}$. For $\mathrm{OC}$, the per capita emissions are higher in $\mathrm{AD} 100$ than in $\mathrm{AD} 1850$ for the high and the intermediate scenarios. For BC, the per capita emissions are only higher for the high emission scenario, while the per capita emissions for $\mathrm{SO}_{2}$ are lower than in $\mathrm{AD} 1850$ for all scenarios.

(a)

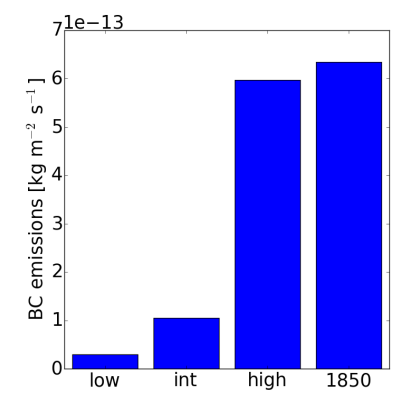

(b)

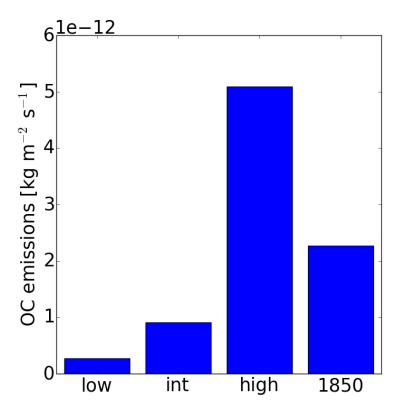

(c)

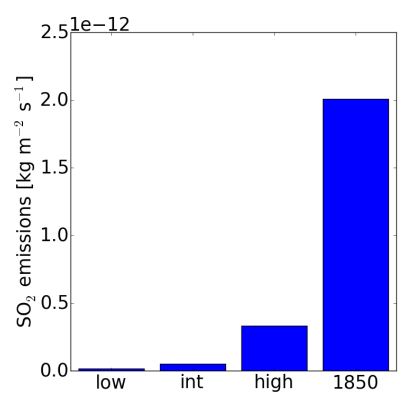

Fig. S3: The annual mean anthropogenic aerosol emissions in AD 100 averaged over the study domain $\left(10^{\circ} \mathrm{W}\right.$ to $50^{\circ} \mathrm{E}, 20^{\circ} \mathrm{N}$ to $60^{\circ} \mathrm{N}$ ) for the low emission scenario (low), the intermediate emission scenario (int), and the high emission scenario (high). Also shown are the anthropogenic aerosol emissions from the ACCMIP inventory for the year AD 1850 averaged over the same region. The emissions for (a) BC, (b) OC, and (c) $\mathrm{SO}_{2}$ are pictured. 
(a)

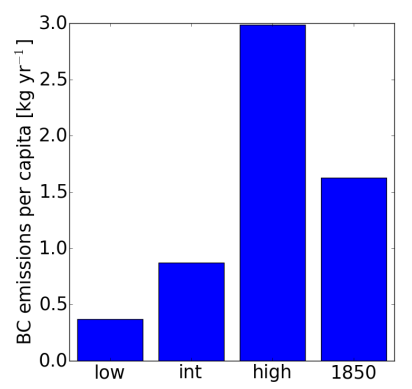

(b)

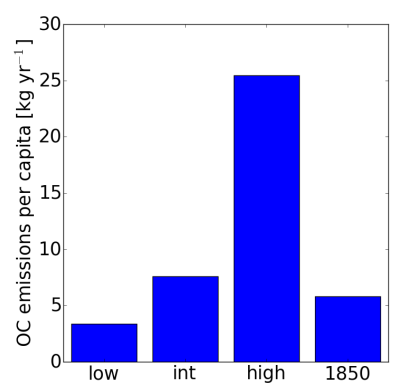

(c)

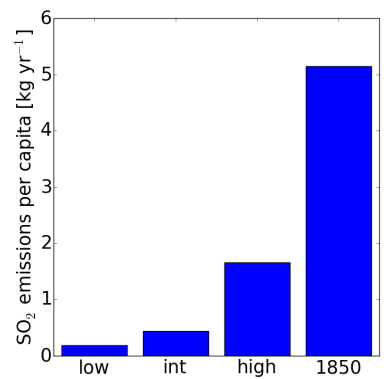

Fig. S4: The same as Figure $\mathrm{S} 3$ but showing per capita emissions.

\section{S11 Comparison between natural fire emissions and anthropogenic emissions in AD 100}

In the following, we compare the anthropogenic aerosol emissions to the natural fire emissions in $\mathrm{AD} 100$; if the anthropogenic aerosol emissions are very low compared to the natural fire emissions, we would not expect any influence of the anthropogenic emissions. On the other hand, if the anthropogenic aerosol emissions are on the same order of magnitude as the natural fire emissions or higher, then they could have an impact on radiation and clouds, depending on the amount of natural aerosols from other sources (i.e. dust, sea salt, organic aerosol emissions from biogenic sources, and sulfate from volcanic, oceanic, and terrestrial sources).

Next to the anthropogenic aerosol emissions, Figs. S5, S6, S7 show also the natural fire emissions used in the simulations without anthropogenic aerosols (no_human, LCC_HYDE, LCC_KK; called "ref" in the figure) and the natural fire emissions for the respective scenarios where the natural fire emissions are set to 0 in areas where crop or pasture grow (LCC_HYDE_low, LCC_HYDE_int, LCC_KK_high; called "LCC" in the figure). By comparing "ref" to the sum of "LCC" and the anthropogenic emissions, the potential impact of the anthropogenic emissions can be estimated.

The anthropogenic emissions have a much less pronounced annual cycle than the natural emissions. Averaged over the whole year, the anthropogenic emissions of the low (Fig. S5b) and the intermediate (Fig. S5c) scenarios are very small compared to natural fire emissions (ref), while the anthropogenic emissions of the high scenario are comparable. However, the comparison strongly depends on the season. For the low emission scenario, the total aerosol emissions from natural fires ("LCC") plus anthropogenic activities are clearly smaller in summer than the natural fire emissions ("ref"), i.e. humans overall reduce aerosol emissions. In contrast, the anthropogenic emissions are clearly higher than the natural fire emissions in winter, as illustrated in Fig. S5a, which shows the months January to March on a different scale (two orders of magnitude lower). For the intermediate emission scenario, the anthropogenic emissions are larger than the natural fire emissions ("ref") for approximately half of the year. The anthropogenic emissions for the high emission scenario are higher than the natural fire emissions for most of the year (Fig. S5d).

For the majority of scenarios and aerosols, the emissions from pasture burning contribute most to the total anthropogenic emissions (Fig. S8). The emissions from fuel consumption are smaller in most cases but on the same order of magnitude (Fig. S8). Averaged over the whole year, the emissions from crop residue burning are relatively small (Fig. S8); however, in summer, 
the emissions are in some cases comparable to pasture burning and/or fuel consumption (e.g. Fig. S8b).

(a)

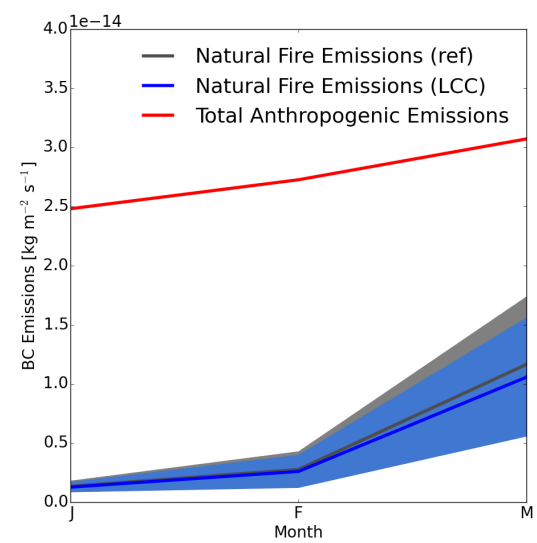

(c)

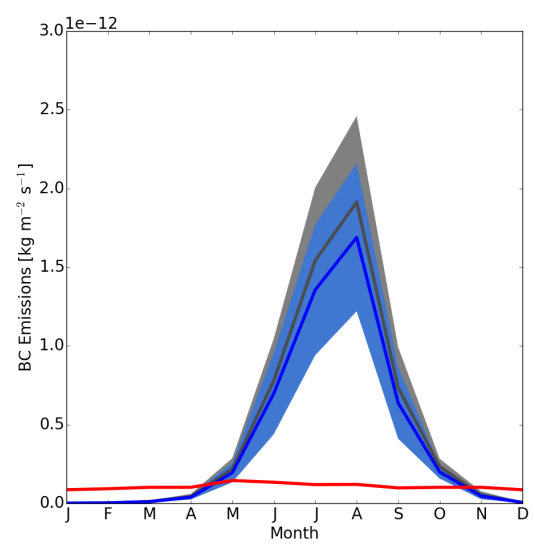

(b)

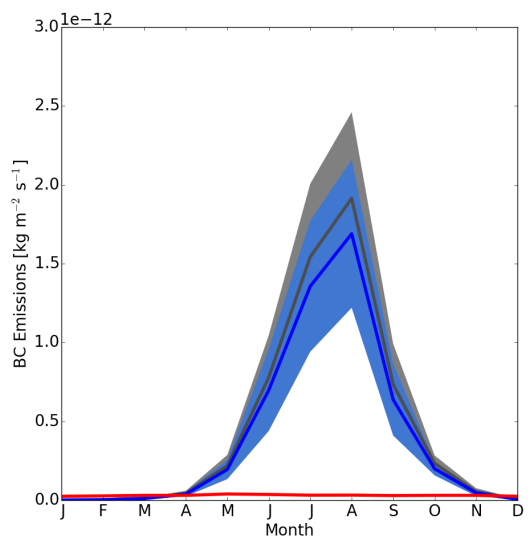

(d)

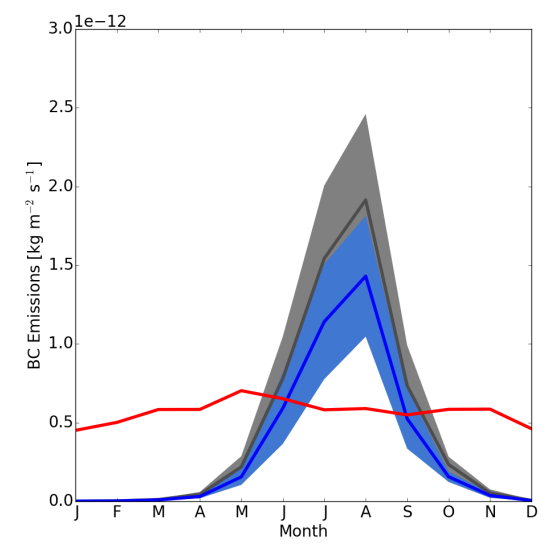

Fig. S5: Monthly averaged BC emissions in our study domain for (a) the beginning of the year and (b)-(d) the whole year. The shadings show the standard deviation for each month over the 20-year period since our natural fire emissions show interannual variability. The grey line shows the natural fire emissions of the simulations no_human, LCC_HYDE, and LCC_KK, whereas the blue line shows the natural fire emissions of the simulations LCC_HYDE_low, LCC_HYDE_int, and LCC_KK_high, in which anthropogenic land cover change reduces the natural fire emissions. The red line shows the total anthropogenic aerosol emissions. In (a) and (b), the BC emissions from the low scenario are shown; note that the values on the y-axis are larger in (b) than in (a). In (c) and (d), the emissions from the intermediate and the high scenarios are shown, respectively. 
(a)

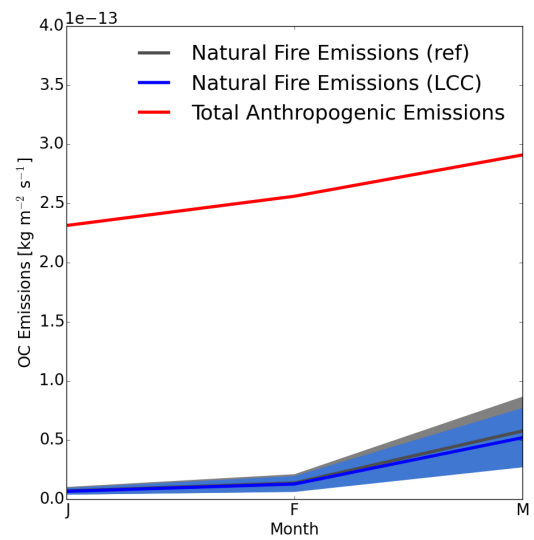

(c)

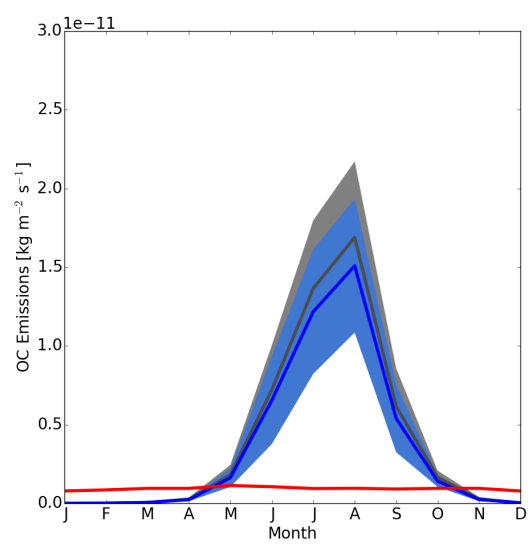

(b)

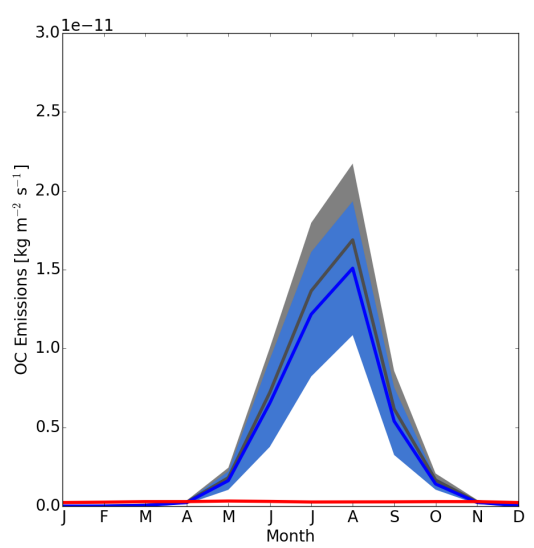

(d)

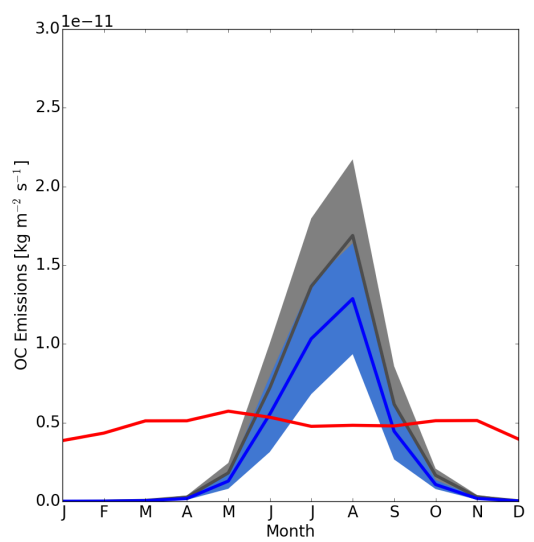

Fig. S6: The same as Fig. S5 but for OC instead of BC. 
(a)

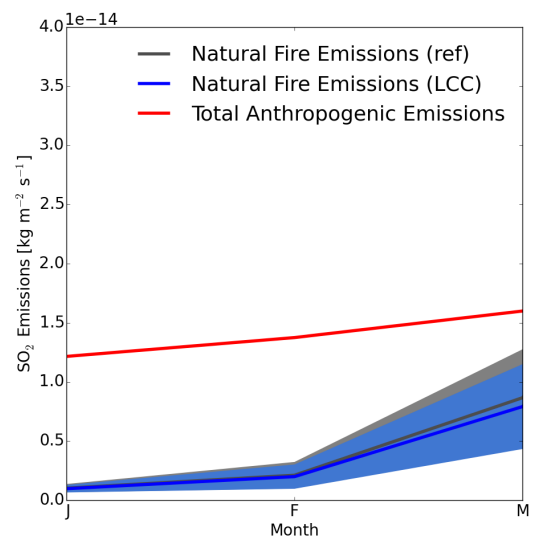

(c)

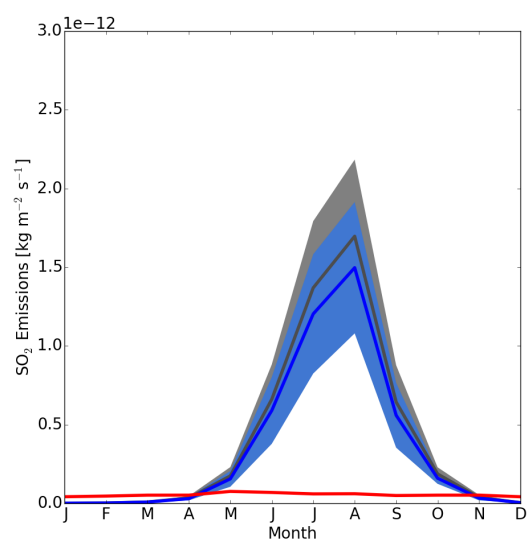

(b)

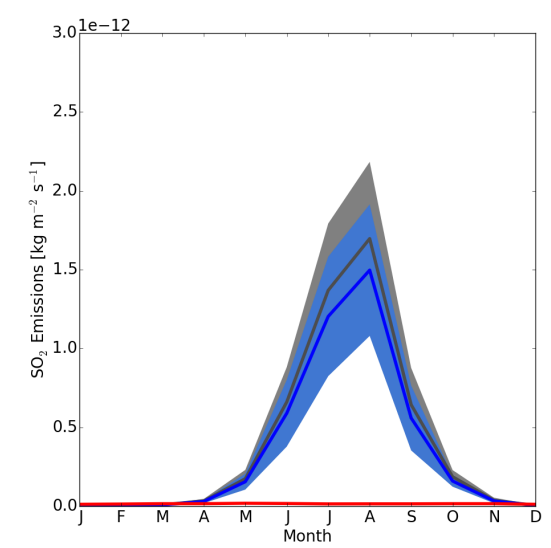

(d)

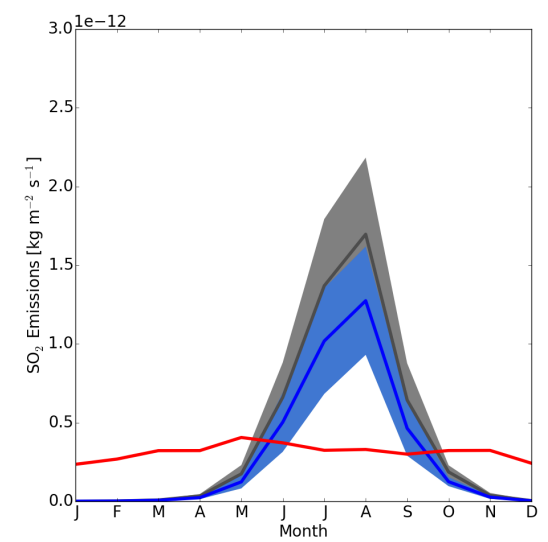

Fig. S7: The same as Fig. $\mathrm{S} 5$ but for $\mathrm{SO}_{2}$ instead of $\mathrm{BC}$. 
(a)

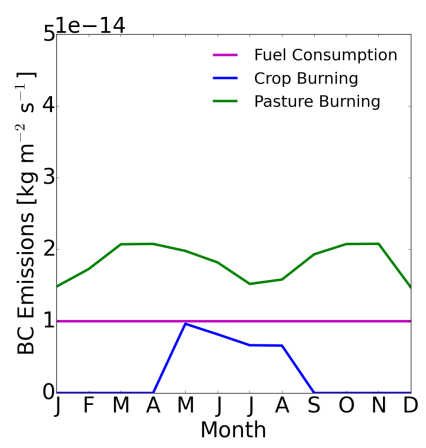

(d)

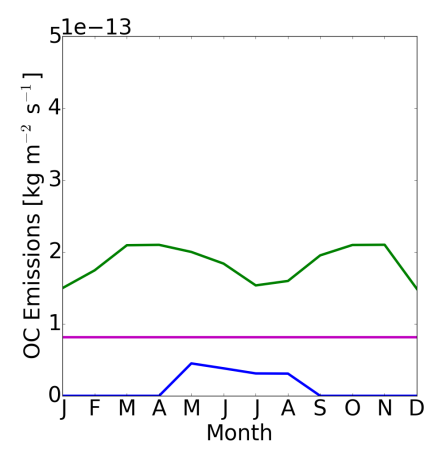

(g)

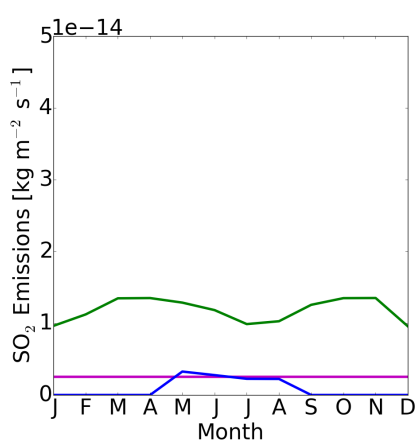

(b)

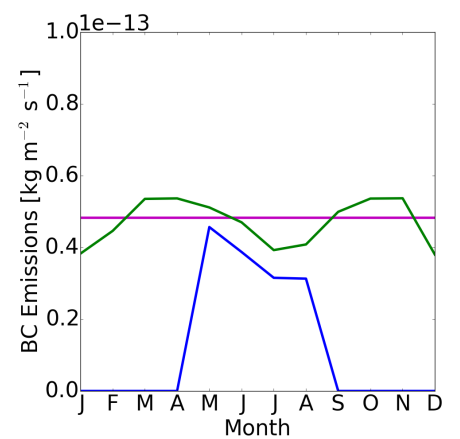

(e)

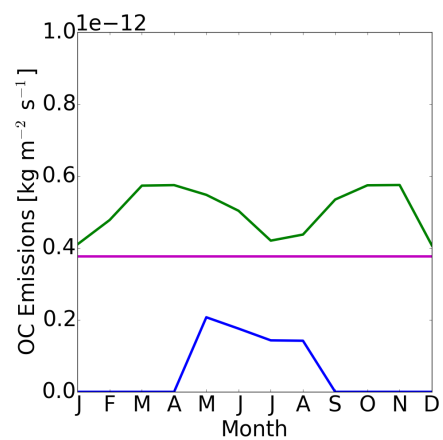

(h)

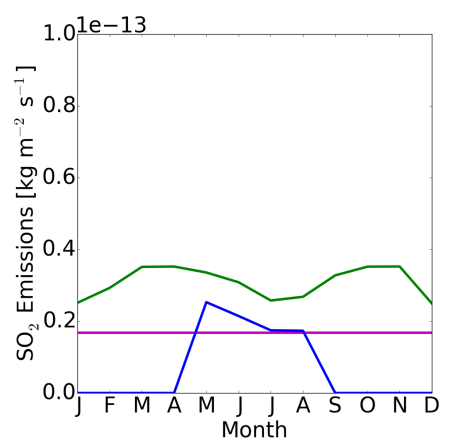

(c)

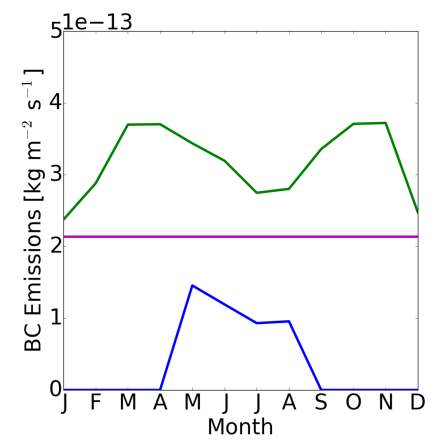

(f)

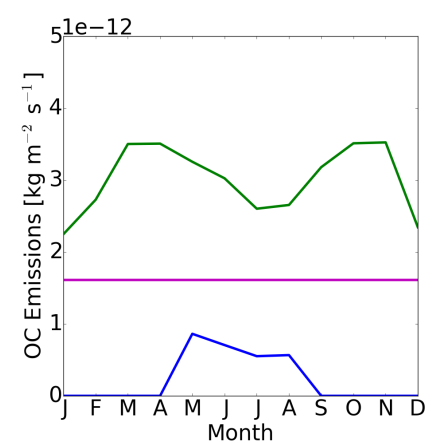

(i)

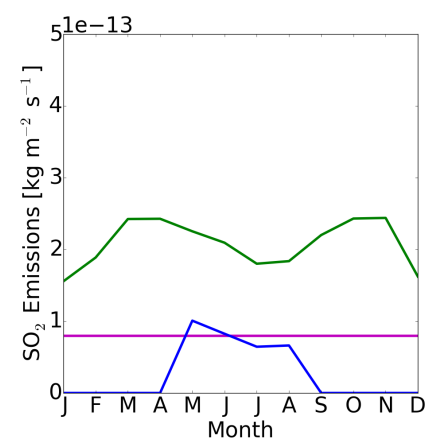

Fig. S8: Anthropogenic aerosol emissions due to fuel consumption, crop residue burning, and pasture burning in the study domain over the year. (a)-(c): BC; (d)-(f): OC; (g)-(i): $\mathrm{SO}_{2}$ emissions. Left: low emission scenario; middle: intermediate emission scenario; right: high emission scenario. Note the different scales on the y-axis. 
Tab. S11: The same as Table S10 but showing results for the simulations LCC_HYDE_int ("int") and LCC_HYDE.

\begin{tabular}{|c|c|c|c|c|c|c|c|c|c|c|c|c|c|c|c|c|}
\hline Var. & Unit & H JJA & & JJA & H SON & int & SON & H DJF & \multicolumn{2}{|c|}{ int DJF } & H MAM & int 1 & MAM & $\mathrm{H}$ year & int & year \\
\hline $\mathrm{BC}$ burden & $\mu \mathrm{g} \mathrm{m} \mathrm{m}^{-2}$ & 538.37 & 454.27 & $(-15.6 \%) *$ * & 170.43 & 153.68 & $(-9.8 \%)$ * * & 2.72 & 14.93 & $(448.8 \%) *$ & 26.46 & 44.12 & $(66.7 \%) *$ & 185.42 & 167.54 & $(-9.6 \%) *$ \\
\hline $\mathrm{OM} \mathrm{b}$ & $\mathrm{m}^{-2}$ & 10151.91 & 8781.79 & $(-13.5 \%) *$ & 3320.51 & 3180.92 & $(-4.2 \%)$ & 677.58 & 850.66 & $(25.5 \%)$ * * & 1242.32 & 1516.03 & $(22.0 \%) *$ & 3865.01 & 3596.95 & $(-6.9 \%) *$ \\
\hline $\mathrm{SO}_{4}$ burden & $\mathrm{m}^{-2}$ & 6331.80 & 6067.79 & $(-4.2 \%)$ & 4569.16 & 4613.68 & $(1.0 \%)$ & 2600.15 & 2682.92 & $(3.2 \%)$ & 3733.66 & 3682.05 & $(-1.4 \%)$ & 4316.42 & 4268.40 & $(-1.1 \%)$ \\
\hline CDNC & $10^{9} \mathrm{~m}^{-2}$ & 30.54 & 34.60 & $(13.3 \%) *$ & 25.66 & 36.36 & $(41.7 \%) *$ & 13.19 & 29.18 & $(121.2 \%) * *$ & 21.92 & 30.86 & $(40.8 \%) *$ & 22.87 & 32.76 & $(43.2 \%) *$ \\
\hline LWP & $\mathrm{g} \mathrm{m}^{-2}$ & 54.89 & 58.96 & $(7.4 \%) *$ & 56.36 & 76.20 & $(35.2 \%)$ * & 39.10 & 77.44 & $(98.1 \%) *$ & 40.13 & 55.60 & $(38.5 \%) *$ & 47.64 & 66.97 & $(40.6 \%) *$ \\
\hline $\mathrm{CC}$ & - & 0.31 & 32 & & 0.51 & 0.53 & $(3.9 \%)$ & 0.58 & 0.62 & & 0.54 & 0.55 & $(2.7 \%) *$ & 0.4 & 0.50 & $(4.2 \%) *$ \\
\hline Precipitation & $\mathrm{mm} \mathrm{d}^{-1}$ & 0.81 & 0.87 & & 1.30 & 1.33 & $(2.2 \%)$ & 1.52 & 1.54 & & 1.28 & 1.23 & $(-4.2 \%)$ & 1.2 & 1.24 & \\
\hline $\mathrm{ARE}$ & $\mathrm{W} \mathrm{m}^{-2}$ & -0.81 & -0.79 & $(-2.8 \%)$ & -0.94 & -0.92 & $(-2.1 \%)$ & -0.51 & -0.43 & $(-16.3 \%)$ * * & -0.40 & -0.05 & $(-88.6 \%) *$ & -0.66 & -0.54 & $(-18.0 \%) *$ \\
\hline CRE & $\mathrm{W} \mathrm{m}^{-2}$ & -22.58 & -24.12 & $(6.9 \%) *$ & -2.91 & -5.96 & (104.79) & 4.60 & -0.86 & $(-118.7 \%)$ * * & -14.12 & -20.77 & $\left(47.1^{C}\right.$ & & -13.01 & $(47.2 \%) *$ \\
\hline $\mathrm{T}_{\mathrm{s}}$ & K & 300.28 & 300.05 & $(-0.2$ & * 290.94 & & $(-0$ & 279.31 & & & 290.25 & 28 & $(-0$ & & 290.02 & $(-0.23) *$ \\
\hline $\mathrm{T}_{2}$ & K & 297.51 & 297.32 & $(-0.19) *$ & 290.24 & 289.98 & $(-0.26) *$ & 280.14 & 280.04 & $(-0.1)$ & 288.31 & 287.96 & $(-0.35) *$ & 289.09 & 288.87 & $(-0.23) *$ \\
\hline
\end{tabular}


Tab. S12: The same as Table S10 but showing results for LCC_KK and LCC_KK_high ("high").

\begin{tabular}{|c|c|c|c|c|c|c|c|c|c|c|c|c|c|c|c|}
\hline Var. & Unit & K JJA & high JJA & KK SON & high & SON & KK DJF & higl & DJF & KK MAM & \multicolumn{2}{|c|}{ high MAM } & KK year & high & year \\
\hline$\overline{\mathrm{BC}}$ burden & $\mu \mathrm{g} \mathrm{m}^{-2}$ & 516.73 & $520.93 \quad(0.8 \%)$ & 169.10 & 233.65 & $(38.2 \%) *$ & 2.67 & 70.53 & $(2542.2 \%) *$ & 26.37 & 131.05 & $(397.0 \%) *$ & 179.61 & 239.89 & $(33.6 \%) *$ \\
\hline $\mathrm{OM} \mathrm{b}$ & $m^{-2}$ & 466.62 & $(0.7 \%)$ & 3210.24 & 1332.61 & $(35.0 \%) *$ & 623.35 & 1600.17 & $(156.7 \%) *$ & 1145.62 & 2634.95 & $(130.0 \%) *$ & 3627.28 & 4540.62 & $(25.2 \%) *$ \\
\hline$O_{4}$ burden & $\mathrm{m}$ & 6280.78 & $6065.80(-3.4 \%)$ & 4646.45 & 4765.02 & $(2.6 \%)$ & 2566.28 & 2820.00 & $(9.9 \%)$ * & 3699.46 & 3729.81 & $(0.8 \%)$ & 4305.81 & 4351.47 & $(1.1 \%)$ \\
\hline CDNC & $\mathrm{m}$ & 29.84 & $42.75(43.3 \%) * *$ & 25.51 & 62.60 & $(145.4 \%) *$ & 11.73 & 67.39 & (474.5\%)* * & 20.36 & 60.85 & $(198.8 \%) *$ & 21.90 & 58.34 & $(166.4 \%) *$ \\
\hline LWP & $\mathrm{g} \mathrm{m}^{-2}$ & 53.48 & $63.23(18.2 \%)$ * * & 55.95 & 91.92 & $(64.3 \%) *$ & 36.07 & 106.09 & $(194.2 \%) *$ & 37.96 & 77.16 & $(103.3 \%) *$ & 45.89 & 84.47 & $(84.1 \%) *$ \\
\hline & - & & $(6.6 \%)$ * * * & 50 & 0.54 & & 0.58 & 0.64 & & 0.53 & 0.58 & & 0.2 & 0.52 & \%)* \\
\hline Precipitation & $\mathrm{m} \mathrm{d}^{-1}$ & 0. & $(5.6 \%)$ & 1.24 & 1.31 & $(6.3 \%)$ & 1.51 & 1.50 & $(-0$ & 1.23 & 1.25 & $(2.2 \%)$ & 1.2 & 1.24 & $(3.1 \%)$ \\
\hline $\mathrm{ARE}$ & $m^{-2}$ & -0.68 & $-0.81 \quad(19.9 \%)$ & -1.00 & -0.97 & $(-2.9 \%)$ & -0.51 & -0.40 & $(-21$ & -0.37 & 0.10 & $(-127.3 \%) *$ & -0.64 & -0.52 & $(-18.7 \%) *$ \\
\hline CRE & $\mathrm{W} \mathrm{m}^{-2}$ & -22.20 & -25.29 (13.9\%)* * * & -3.13 & -7.21 & $(130.0 \%)$ *水 & 4.59 & -4.33 & $(-194.3 \%)$ * * & -13.28 & -27.69 & $(108.5 \%)$ * * & -8.58 & -16.21 & $(88.9 \%) *$ \\
\hline $\mathrm{T}_{\mathrm{s}}$ & K & 300.43 & $300.02(-0.41) *$ & 290.94 & 290.63 & $(-0.32) *$ & 279.38 & 279.14 & $(-0$ & 290.23 & 289.35 & $(-0.88) *$ & 290.30 & 289.84 & $(-0.46) *$ \\
\hline $\mathrm{T}_{2}$ temp2 & $\mathrm{K}$ & 297.51 & $297.19(-0.33) *$ & 290.20 & 289.91 & $(-0.28) *$ & 280.20 & 279.89 & $(-0.31)$ & 288.24 & 287.47 & $(-0.76) *$ & 289.08 & 288.66 & $(-0.42) *$ \\
\hline
\end{tabular}




\section{S13 Comparison between CBALONE-SPITFIRE emissions and emissions by van Marle et al. (2017)}

Here, we compare the CBALONE-SPITFIRE emissions for AD 1835 with the emissions of van Marle et al. (2017) for AD 1835, which could show biases in the fire model. The reconstructed emissions by van Marle et al. (2017) are used as input for simulations in the context of the Climate Model Intercomparison Project phase 6; we therefore call them "CMIP6 emissions" in the following. The CMIP6 emissions were calculated by merging satellite data with proxies for biomass burning (e.g. charcoal records and visibility observations) next to using the average of six fire models. The emissions simulated by CBALONE-SPITFIRE are not totally independent of the CMIP6 emissions because 3 of the 6 models considered by van Marle et al. (2017) include SPITFIRE (one of them was JSBACH-SPITFIRE).

The global averages of the fire emissions are relatively similar between CBALONE-SPITFIRE and CMIP6 for AD 1835 (Table S13). The values are somewhat larger for CBALONE-SPITFIRE, namely a factor of 1.2 for $\mathrm{SO}_{2}$ and a factor of 1.7 for $\mathrm{BC}$ and $\mathrm{OC}$ emissions. However, one should keep in mind that the fire emissions by CMIP6 are not the truth and also uncertain. For example, Hamilton et al. (2018) concluded that the CMIP6 pre-industrial fire emissions are likely underestimated.

Although global averages are similar, CBALONE-SPITFIRE simulates pronouncedly higher aerosol emissions compared to CMIP6 for AD 1835 in our study domain (Tables S14, S15, S16). The disagreement is larger in summer and autumn (CBALONE-SPITFIRE 7 to 15 times higher) than in winter and spring (CBALONE-SPITFIRE 2 and 4 times higher). Furthermore, the fire emissions in winter are more located to the South in CBALONE-SPITFIRE; it simulates basically no fires in Eastern Europe in contrast to CMIP6, but higher emissions in North Africa and the Middle East (not shown). Note that the majority ( $\approx 80 \%$ in AD 1850) of the CMIP6 fire emissions in the study domain originates from agricultural crop waste burning on field, whereas crop area is excluded from burning in CBALONE-SPITFIRE. The CBALONE-SPITFIRE emissions could differ from the CMIP6 emissions over Europe because the first are only model-based, while the latter also include observational data. Furthermore, the models considered by van Marle et al. (2017) were driven by different forcing data than our CBALONE-SPITFIRE simulations.

Overall, the fire emissions calculated with CBALONE-SPITFIRE are larger than the CMIP6 emissions in the study domain in $\mathrm{AD}$ 1835. As a consequence, the natural fire emissions calculated for AD 100 could be overestimated in the study domain.

Tab. S13: Global mean fire emissions (in $10^{-14} \mathrm{~kg} \mathrm{~m}^{-2} \mathrm{~s}^{-1}$ ) around AD 1835 used for CMIP6 and those calculated with CBALONE-SPITFIRE ("CBAL-SPIT"). The data covers 20 years around AD 1835 (AD 1823-1842).

\begin{tabular}{c|c|c}
\hline & CMIP6 & CBAL-SPIT \\
\hline BC & 10.0 & 17.0 \\
OC & 84.6 & 141 \\
$\mathrm{SO}_{2}$ & 12.5 & 14.5 \\
\hline
\end{tabular}

Comparing the two CBALONE-SPITFIRE simulations (AD 1835 versus AD 100; Tables S14, S15, S16) reveals that emissions in AD 1835 were somewhat lower in summer compared to AD 100. However, for the other seasons, the emissions in AD 1835 are higher, especially in winter (a factor of 6). The differences can partly be explained by the differences in the population density; for $\mathrm{AD}$ 100, only natural fires were calculated and the population density was thus 
Tab. S14: Mean BC fire emissions (in $10^{-14} \mathrm{~kg} \mathrm{~m}^{-2} \mathrm{~s}^{-1}$ ) averaged from $10^{\circ} \mathrm{W}$ to $50^{\circ} \mathrm{E}$ and from $20^{\circ} \mathrm{N}$ to $60^{\circ} \mathrm{N}$ used for CMIP6 and those calculated with CBALONE-SPITFIRE ("CBAL-SPIT"). The data covers 20 years around AD 1835 (AD 1823-1842).

\begin{tabular}{l|r|r|c}
\hline & CMIP6 AD 1835 & CBAL-SPIT AD 1835 & CBAL-SPIT AD 100 \\
\hline Autumn & 6.65 & 62.4 & 33.9 \\
Winter & 0.470 & 1.95 & 0.339 \\
Spring & 6.29 & 16.7 & 9.20 \\
Summer & 14.8 & 135 & 142 \\
\hline
\end{tabular}

Tab. S15: The same as Table $\mathrm{S} 14$ but for OC and in $10^{-13} \mathrm{~kg} \mathrm{~m}^{-2} \mathrm{~s}^{-1}$.

\begin{tabular}{l|c|r|c}
\hline & CMIP6 AD 1835 & CBAL-SPIT AD 1835 & CBAL-SPIT AD 100 \\
\hline Autumn & 2.80 & 43.0 & 26.9 \\
Winter & 0.295 & 1.07 & 0.178 \\
Spring & 3.39 & 11.1 & 7.14 \\
Summer & 6.77 & 101 & 126 \\
\hline
\end{tabular}

Tab. S16: The same as Table $\mathrm{S} 14$ but for $\mathrm{SO}_{2}$ (in $10^{-14} \mathrm{~kg} \mathrm{~m}^{-2} \mathrm{~s}^{-1}$ ).

\begin{tabular}{l|r|r|c}
\hline & CMIP6 AD 1835 & CBAL-SPIT AD 1835 & CBAL-SPIT AD 100 \\
\hline Autumn & 4.54 & 40.2 & 28.8 \\
Winter & 0.435 & 1.57 & 0.250 \\
Spring & 5.06 & 10.2 & 7.27 \\
Summer & 10.8 & 78.7 & 125 \\
\hline
\end{tabular}

set to 0 (Sect. S3). In the model, population shortens the fire duration but at the same time increases the number of ignition events. While the first effect dominates in summer, the second one dominates in the other seasons. Furthermore, differences in anthropogenic land cover (none assumed for $\mathrm{AD}$ 100), natural vegetation, and climate can also contribute to the differences between AD 1835 and AD 100. 


\begin{tabular}{|c|c|c|c|c|c|c|c|c|c|c|}
\hline Burning material & $\mathrm{OC}$ & & $\mathrm{BC}$ & & $\mathrm{SO}_{2}$ & & $N$ & Reference & Burning/ measurement device & Key \\
\hline & average & std & average & std & average & std & & & & \\
\hline UP dung & 7.1970 & 6.7530 & 0.5657 & 0.4949 & & & 7 & $\begin{array}{l}\text { Pandey et al. } \\
(2017)\end{array}$ & $\begin{array}{l}\text { traditional cooking-stove, In- } \\
\text { dia }\end{array}$ & 2 \\
\hline Bihar dung & 10.6500 & 10.0300 & 0.9700 & 0.8403 & & & 6 & $\begin{array}{l}\text { Pandey et al. } \\
(2017)\end{array}$ & $\begin{array}{l}\text { traditional cooking-stove, In- } \\
\text { dia }\end{array}$ & 2 \\
\hline Chh rice straw & 7.0786 & 5.1236 & 1.1157 & 1.3508 & & & 7 & $\begin{array}{l}\text { Pandey et al. } \\
(2017)\end{array}$ & $\begin{array}{l}\text { traditional cooking-stove, In- } \\
\text { dia }\end{array}$ & 2 \\
\hline Chh tur stalk & 8.0880 & 6.1330 & 1.9580 & 1.8140 & & & 10 & $\begin{array}{l}\text { Pandey et al. } \\
(2017)\end{array}$ & $\begin{array}{l}\text { traditional cooking-stove, In- } \\
\text { dia }\end{array}$ & 2 \\
\hline Punjab wood & 2.6000 & 2.3780 & 0.6750 & 0.4387 & & & 4 & $\begin{array}{l}\text { Pandey et al. } \\
(2017)\end{array}$ & $\begin{array}{l}\text { traditional cooking-stove, In- } \\
\text { dia }\end{array}$ & 1 \\
\hline Raj wood & 5.4041 & 5.0848 & 1.1410 & 1.0134 & & & 17 & $\begin{array}{l}\text { Pandey et al. } \\
(2017)\end{array}$ & $\begin{array}{l}\text { traditional cooking-stove, In- } \\
\text { dia }\end{array}$ & 1 \\
\hline UP wood & 2.1363 & 1.1830 & 0.5500 & 0.3464 & & & 8 & $\begin{array}{l}\text { Pandey et al. } \\
(2017)\end{array}$ & $\begin{array}{l}\text { traditional cooking-stove, In- } \\
\text { dia }\end{array}$ & 1 \\
\hline AP wood & 5.0125 & 3.6248 & 0.4550 & 0.2664 & & & 4 & $\begin{array}{l}\text { Pandey et al. } \\
(2017)\end{array}$ & $\begin{array}{l}\text { traditional cooking-stove, In- } \\
\text { dia }\end{array}$ & 1 \\
\hline wheat straw & 3.4600 & 2.0500 & 0.4200 & 0.2300 & 0.0400 & 0.0400 & 8 & Cao et al. (2008) & $\begin{array}{l}\text { combustion tower (simulating } \\
\text { cooking in traditional stoves) }\end{array}$ & 2 \\
\hline rice straw & 2.0100 & 0.6700 & 0.4900 & 0.2100 & 0.1800 & 0.3100 & 14 & Cao et al. (2008) & $\begin{array}{l}\text { combustion tower (simulating } \\
\text { cooking in traditional stoves) }\end{array}$ & 2 \\
\hline
\end{tabular}




\begin{tabular}{|c|c|c|c|c|c|c|c|c|c|c|}
\hline cotton stalk & 1.8300 & 0.5400 & 0.8200 & 0.2000 & 0.0400 & 0.0400 & 2 & $\begin{array}{l}\text { Cao et al. } 2008) \\
\text { Cao et al. }(2008)\end{array}$ & $\begin{array}{l}\text { combustion tower (simulating } \\
\text { cooking in traditional stoves) } \\
\text { combustion tower (simulating } \\
\text { cooking in traditional stoves) }\end{array}$ & 2 \\
\hline rice straw & 0.9000 & 0.4500 & 0.4600 & 0.2300 & & & 7 & Turn et al. (1997) & wind tunnel & $3 \mathrm{a}$ \\
\hline wheat straw & 2.1000 & 1.0500 & 0.7900 & 0.3950 & & & 2 & Turn et al. (1997) & wind tunnel & $3 \mathrm{a}$ \\
\hline barley straw & 3.0000 & 1.5000 & 1.2000 & 0.6000 & & & 2 & Turn et al. (1997) & wind tunnel & $3 \mathrm{a}$ \\
\hline corn stover & 1.7000 & 0.8500 & 0.6700 & 0.3350 & & & 2 & Turn et al. (1997) & wind tunnel & $3 \mathrm{a}$ \\
\hline sugar cane & 1.5000 & 0.7500 & 0.5900 & 0.2950 & & & 3 & Turn et al. (1997) & wind tunnel & $3 \mathrm{a}$ \\
\hline wheat straw & 2.8130 & 0.1470 & 0.6760 & 0.0270 & & & 4 & Li et al. $(2017)$ & $\begin{array}{l}\text { combustion stove to simulate } \\
\text { open burning }\end{array}$ & 3 \\
\hline corn straw & 2.3930 & 0.3510 & 0.7780 & 0.1520 & & & 4 & Li et al. (2017) & $\begin{array}{l}\text { combustion stove to simulate } \\
\text { open burning }\end{array}$ & 3 \\
\hline rice straw & 6.8820 & 0.6890 & 2.1820 & 0.2780 & & & 4 & Li et al. (2017) & $\begin{array}{l}\text { combustion stove to simulate } \\
\text { open burning }\end{array}$ & 3 \\
\hline cotton residue & 7.4150 & 0.5470 & 1.1920 & 0.1710 & & & 4 & Li et al. (2017) & $\begin{array}{l}\text { combustion stove to simulate } \\
\text { open burning }\end{array}$ & 3 \\
\hline soybean residue & 1.5390 & 0.2530 & 0.6140 & 0.1900 & & & 4 & Li et al. $(2017)$ & $\begin{array}{l}\text { combustion stove to simulate } \\
\text { open burning }\end{array}$ & 3 \\
\hline Maize-brick & & & & & 0.0163 & 0.0104 & 3 & $\begin{array}{l}\text { Zhang et al. } \\
(2000)\end{array}$ & brick stove with flue & 2 \\
\hline Wood-India & & & & & 0.0024 & 0.0024 & 3 & Zhang et al. & $\begin{array}{l}\text { metal stove without flue (from } \\
\text { India) }\end{array}$ & 1 \\
\hline Wheat-brick & & & & & 0.0335 & 0.0174 & 3 & Zhang et al. & brick stove with flue & 2 \\
\hline Brush-brick & & & & & 0.0056 & 0.0077 & 3 & Zhang et al. & brick stove with flue & 2 \\
\hline Brush-India & & & & & 0.0025 & 0.0044 & 3 & Zhang et al. & $\begin{array}{l}\text { metal stove without flue (from } \\
\text { India) }\end{array}$ & 2 \\
\hline
\end{tabular}




\begin{tabular}{|c|c|c|c|c|c|c|c|c|}
\hline $\begin{array}{l}\text { fireplace, soft- } \\
\text { wood }\end{array}$ & 3.0073 & 0.3335 & 0.7742 & 0.0697 & 3 & $\begin{array}{l}\text { McDonald et al. } \\
(2000)\end{array}$ & heatilator model E36 fireplace & 1 \\
\hline $\begin{array}{l}\text { fireplace, hard- } \\
\text { wood }\end{array}$ & 3.5800 & 0.7981 & 0.3975 & 0.1177 & 3 & McDonald et al. & heatilator model E36 fireplace & 1 \\
\hline $\begin{array}{l}\text { wood stove, hard- } \\
\text { wood }\end{array}$ & 2.8211 & 1.7706 & 0.3563 & 0.2169 & 3 & McDonald et al. & $\begin{array}{l}\text { noncatalytic Pineridge appli- } \\
\text { cance }\end{array}$ & 1 \\
\hline maritime pine & 6.1344 & 3.0672 & 1.0650 & 0.5325 & 3 & Alves et al. $(2011)$ & $\begin{array}{l}\text { traditional Portuguese brick } \\
\text { open fireplace }\end{array}$ & $1 \mathrm{a}$ \\
\hline eucalypt & 8.7264 & 4.3632 & 0.4444 & 0.2222 & 3 & Alves et al. (2011) & $\begin{array}{l}\text { traditional Portuguese brick } \\
\text { open fireplace }\end{array}$ & $1 \mathrm{a}$ \\
\hline cork oak & 6.9412 & 3.4706 & 0.3484 & 0.1742 & 3 & Alves et al. (2011) & $\begin{array}{l}\text { traditional Portuguese brick } \\
\text { open fireplace }\end{array}$ & $1 \mathrm{a}$ \\
\hline golden wattle & 3.8700 & 1.9350 & 0.6600 & 0.3300 & 3 & Alves et al. (2011) & $\begin{array}{l}\text { traditional Portuguese brick } \\
\text { open fireplace }\end{array}$ & $1 \mathrm{a}$ \\
\hline olive & 4.8015 & 2.4008 & 0.4158 & 0.2079 & 3 & Alves et al. (2011) & $\begin{array}{l}\text { traditional Portuguese brick } \\
\text { open fireplace }\end{array}$ & $1 \mathrm{a}$ \\
\hline Portugese oak & 9.1680 & 4.5840 & 0.4775 & 0.2388 & 3 & Alves et al. (2011) & $\begin{array}{l}\text { traditional Portuguese brick } \\
\text { open fireplace }\end{array}$ & $1 \mathrm{a}$ \\
\hline holm oak & 8.4800 & 4.2400 & 0.3520 & 0.1760 & 3 & Alves et al. (2011) & $\begin{array}{l}\text { traditional Portuguese brick } \\
\text { open fireplace }\end{array}$ & $1 \mathrm{a}$ \\
\hline maritime pine & 8.0196 & 4.0098 & 0.6357 & 0.3179 & 3 & Alves et al. (2011) & $\begin{array}{l}\text { a cast iron woodstove (Solza- } \\
\text { ima, model Sahara) }\end{array}$ & $1 \mathrm{a}$ \\
\hline eucalypt & 3.2160 & 1.6080 & 0.2479 & 0.1240 & 3 & Alves et al. (2011) & $\begin{array}{l}\text { a cast iron woodstove (Solza- } \\
\text { ima, model Sahara) }\end{array}$ & $1 \mathrm{a}$ \\
\hline cork oak & 8.0936 & 4.0468 & 0.2869 & 0.1435 & 3 & Alves et al. (2011) & $\begin{array}{l}\text { a cast iron woodstove (Solza- } \\
\text { ima, model Sahara) }\end{array}$ & $1 \mathrm{a}$ \\
\hline golden wattle & 5.2650 & 2.6325 & 0.2340 & 0.1170 & 3 & Alves et al. (2011) & $\begin{array}{l}\text { a cast iron woodstove (Solza- } \\
\text { ima, model Sahara) }\end{array}$ & $1 \mathrm{a}$ \\
\hline
\end{tabular}




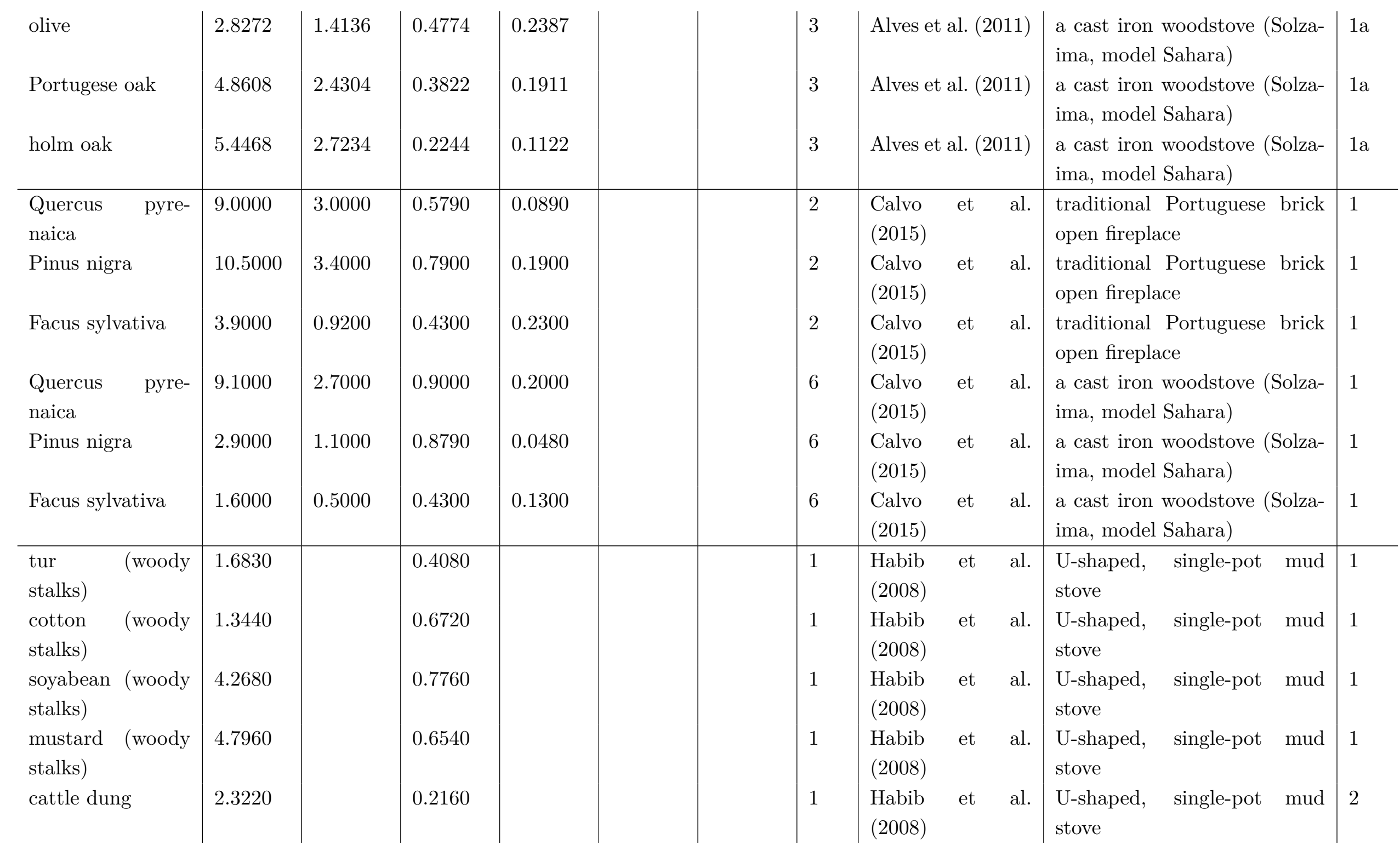




\begin{tabular}{|c|c|c|c|c|c|c|c|c|}
\hline \multirow{2}{*}{$\begin{array}{l}\text { jute (fibrous hol- } \\
\text { low stalks) } \\
\text { rice straw }\end{array}$} & 0.6290 & & 0.3060 & & 1 & Habib et al. & $\begin{array}{l}\text { U-shaped, single-pot mud } \\
\text { stove }\end{array}$ & 2 \\
\hline & 4.6500 & & 0.1860 & & 1 & $\begin{array}{l}\text { Habib et al. } \\
(2008)\end{array}$ & $\begin{array}{l}\text { U-shaped, single-pot mud } \\
\text { stove }\end{array}$ & 2 \\
\hline jamun & 1.5800 & 2.0300 & 0.4800 & 0.0850 & 2 & $\begin{array}{l}\text { Habib et al. } \\
(2008)\end{array}$ & $\begin{array}{l}\text { U-shaped, single-pot mud } \\
\text { stove }\end{array}$ & 1 \\
\hline neem & 1.6500 & 1.9500 & 0.6100 & 0.0300 & 2 & $\begin{array}{l}\text { Habib et al. } \\
(2008)\end{array}$ & $\begin{array}{l}\text { U-shaped, single-pot mud } \\
\text { stove }\end{array}$ & 1 \\
\hline mango & 1.6100 & 1.5700 & 0.6400 & 0.0640 & 2 & $\begin{array}{c}\text { Habib et al. } \\
(2008)\end{array}$ & $\begin{array}{l}\text { U-shaped, single-pot mud } \\
\text { stove }\end{array}$ & 1 \\
\hline Acacia & 1.1000 & 0.5390 & 0.4500 & 0.1220 & 2 & $\begin{array}{l}\text { Habib } \\
(2008)\end{array}$ & $\begin{array}{l}\text { U-shaped, single-pot mud } \\
\text { stove }\end{array}$ & 1 \\
\hline horsebean & 1.2000 & 0.1700 & 1.2800 & 0.1000 & 2 & Shen et al. $(2010)$ & brick wok stove (rural) & 2 \\
\hline peanut & 1.0800 & & 0.4930 & & 1 & Shen et al. (2010) & brick wok stove (rural) & 2 \\
\hline soybean residue & 1.1700 & 0.1800 & 1.3700 & 0.0400 & 2 & Shen et al. (2010) & brick wok stove (rural) & 2 \\
\hline cotton residue & 0.3540 & 0.0410 & 1.3400 & 0.5800 & 2 & Shen et al. $(2010)$ & brick wok stove (rural) & 2 \\
\hline rice & 1.5000 & 0.1600 & 0.7490 & 0.4270 & 2 & Shen et al. (2010) & brick wok stove (rural) & 2 \\
\hline wheat & 2.2700 & 1.3000 & 2.6400 & 1.0100 & 2 & Shen et al. (2010) & brick wok stove (rural) & 2 \\
\hline rape & 1.7500 & 0.6300 & 2.3400 & 0.9200 & 2 & Shen et al. $(2010)$ & brick wok stove (rural) & 2 \\
\hline sesame & 2.3400 & 1.1200 & 1.0700 & 0.0300 & 2 & Shen et al. (2010) & brick wok stove (rural) & 2 \\
\hline corn & 1.3600 & 0.2900 & 1.1100 & 0.0800 & 2 & Shen et al. $(2010)$ & brick wok stove (rural) & 2 \\
\hline wheat stubble & 1.3794 & 0.3012 & 0.4260 & 0.1147 & 3 & $\begin{array}{l}\text { Jimenez et al. } \\
(2007)\end{array}$ & $\begin{array}{l}\text { test burn chamber to mimic } \\
\text { open burn conditions }\end{array}$ & 3 \\
\hline wheat stubble & 2.8120 & 1.6127 & 0.1660 & 0.1408 & 6 & $\begin{array}{l}\text { Jimenez et al. } \\
(2007)\end{array}$ & open field & 3 \\
\hline $\begin{array}{l}\text { Kentucky Blue- } \\
\text { grass }\end{array}$ & 5.2248 & 2.2406 & 0.7650 & 0.3361 & 2 & $\begin{array}{l}\text { Jimenez et al. } \\
(2007)\end{array}$ & open field & 4 \\
\hline $\begin{array}{l}\text { Kentucky Blue- } \\
\text { grass }\end{array}$ & 4.4637 & 1.2962 & 0.8155 & 0.4307 & 4 & $\begin{array}{l}\text { Jimenez et al. } \\
(2007)\end{array}$ & $\begin{array}{l}\text { test burn chamber to mimic } \\
\text { open burn conditions }\end{array}$ & 4 \\
\hline
\end{tabular}




\begin{tabular}{|c|c|c|c|c|c|c|c|c|}
\hline wheat straw & 0.2900 & 0.1200 & 0.1600 & 0.0700 & & Sahai et al. (2007) & field burning & 3 \\
\hline wheat straw & 2.3800 & & 1.5900 & & 1 & Sahai et al. $(2007)$ & $\begin{array}{l}\text { earlier lab experiments at } \\
\text { NPL }\end{array}$ & 3 \\
\hline wheat straw & 1.2300 & & 0.5200 & & 1 & Hays et al. (2005) & field open burn simulations & 3 \\
\hline rice straw & 8.9400 & & 0.1700 & & 1 & Hays et al. (2005) & field open burn simulations & 3 \\
\hline olive pits & 0.9000 & 0.5700 & 0.1000 & 0.0600 & & $\begin{array}{l}\text { AIRUSE LIFE } \\
(2016)\end{array}$ & from pellet stove & 2 \\
\hline maritime pine & 2.5400 & 2.5100 & 0.6100 & 0.4300 & 3 & Fernandes et al. & $\begin{array}{l}\text { a cast iron woodstove (Solza- } \\
\text { ima, model Sahara) }\end{array}$ & 1 \\
\hline golden wattle & 4.0700 & 2.6500 & 0.2900 & 0.1800 & 3 & Fernandes et al. & $\begin{array}{l}\text { a cast iron woodstove (Solza- } \\
\text { ima, model Sahara) }\end{array}$ & 1 \\
\hline eucalypt & 5.1600 & 4.0300 & 0.3700 & 0.3000 & 3 & $\begin{array}{l}\text { Fernandes et al. } \\
(2011)\end{array}$ & $\begin{array}{l}\text { a cast iron woodstove (Solza- } \\
\text { ima, model Sahara) }\end{array}$ & 1 \\
\hline cork oak & 4.8000 & 3.3800 & 0.4200 & 0.3300 & 3 & $\begin{array}{l}\text { Fernandes et al. } \\
(2011)\end{array}$ & $\begin{array}{l}\text { a cast iron woodstove (Solza- } \\
\text { ima, model Sahara) }\end{array}$ & 1 \\
\hline olive & 4.5500 & 2.2200 & 0.4600 & 0.2400 & 3 & Fernandes et al. & $\begin{array}{l}\text { a cast iron woodstove (Solza- } \\
\text { ima, model Sahara) }\end{array}$ & 1 \\
\hline holm oak & 3.0300 & 2.0500 & 0.2300 & 0.0900 & 3 & $\begin{array}{l}\text { Fernandes et al. } \\
(2011)\end{array}$ & $\begin{array}{l}\text { a cast iron woodstove (Solza- } \\
\text { ima, model Sahara) }\end{array}$ & 1 \\
\hline Portugese oak & 6.1700 & 4.6200 & 0.3200 & 0.1500 & 3 & $\begin{array}{l}\text { Fernandes et al. } \\
(2011)\end{array}$ & $\begin{array}{l}\text { a cast iron woodstove (Solza- } \\
\text { ima, model Sahara) }\end{array}$ & 1 \\
\hline maritime pine & 2.9100 & 1.3000 & 0.6200 & 0.4900 & 3 & $\begin{array}{l}\text { Fernandes et al. } \\
(2011)\end{array}$ & $\begin{array}{l}\text { traditional Portuguese brick } \\
\text { open fireplace }\end{array}$ & 1 \\
\hline golden wattle & 3.5300 & 3.1300 & 0.3400 & 0.2600 & 3 & $\begin{array}{l}\text { Fernandes et al. } \\
(2011)\end{array}$ & $\begin{array}{l}\text { traditional Portuguese brick } \\
\text { open fireplace }\end{array}$ & 1 \\
\hline eucalypt & 5.1100 & 3.9000 & 0.3600 & 0.3600 & 3 & $\begin{array}{l}\text { Fernandes et al. } \\
(2011)\end{array}$ & $\begin{array}{l}\text { traditional Portuguese brick } \\
\text { open fireplace }\end{array}$ & 1 \\
\hline
\end{tabular}




\begin{tabular}{|c|c|c|c|c|c|c|c|c|}
\hline cork oak & 10.0600 & 5.2400 & 0.6800 & 0.4000 & 3 & $\begin{array}{l}\text { Fernandes et al. } \\
(2011)\end{array}$ & $\begin{array}{l}\text { traditional Portuguese brick } \\
\text { open fireplace }\end{array}$ & 1 \\
\hline olive & 9.1000 & 5.7400 & 0.3900 & 0.1600 & 3 & $\begin{array}{l}\text { Fernandes et al. } \\
(2011)\end{array}$ & $\begin{array}{l}\text { traditional Portuguese brick } \\
\text { open fireplace }\end{array}$ & 1 \\
\hline holm oak & 7.2200 & 4.0300 & 0.3000 & 0.1100 & 3 & $\begin{array}{l}\text { Fernandes et al. } \\
(2011)\end{array}$ & $\begin{array}{l}\text { traditional Portuguese brick } \\
\text { open fireplace }\end{array}$ & 1 \\
\hline Portugese oak & 6.0600 & 3.4000 & 0.3200 & 0.2000 & 3 & $\begin{array}{l}\text { Fernandes et al. } \\
(2011)\end{array}$ & $\begin{array}{l}\text { traditional Portuguese brick } \\
\text { open fireplace }\end{array}$ & 1 \\
\hline $\begin{array}{l}\text { Chinese white } \\
\text { poplar }\end{array}$ & 0.6600 & 0.3200 & 0.8800 & 0.4900 & 3 & $\begin{array}{l}\text { Guofeng et al. } \\
(2012)\end{array}$ & brick stove (rural) & 1 \\
\hline elm & 0.7900 & 0.1500 & 1.2000 & 0.3000 & 3 & $\begin{array}{l}\text { Guofeng et al. } \\
(2012)\end{array}$ & brick stove (rural) & 1 \\
\hline yellow locust & 1.9000 & 1.5000 & 0.2100 & 0.1500 & 3 & $\begin{array}{l}\text { Guofeng et al. } \\
(2012)\end{array}$ & brick stove (rural) & 1 \\
\hline maple & 0.1100 & 0.0100 & 0.0560 & 0.0040 & 3 & $\begin{array}{l}\text { Guofeng et al. } \\
(2012)\end{array}$ & brick stove (rural) & 1 \\
\hline fir & 0.9700 & 0.8800 & 0.9500 & 0.2000 & 3 & Guofeng et al. & brick stove (rural) & 1 \\
\hline larch & 0.1400 & 0.1100 & 0.3500 & 0.3400 & 3 & $\begin{array}{l}\text { Guofeng et al. } \\
(2012)\end{array}$ & brick stove (rural) & 1 \\
\hline water Chinese fir & 0.3600 & 0.1700 & 0.8500 & 0.4500 & 3 & $\begin{array}{l}\text { Guofeng et al. } \\
(2012)\end{array}$ & brick stove (rural) & 1 \\
\hline cypress & 0.8200 & 0.4500 & 0.7100 & 0.3900 & 3 & Guofeng et al. & brick stove (rural) & 1 \\
\hline oak & 0.5400 & 0.6300 & 0.1300 & 0.1300 & 3 & $\begin{array}{l}\text { Guofeng et al. } \\
(2012)\end{array}$ & brick stove (rural) & 1 \\
\hline chinese pine & 0.6000 & 0.3500 & 0.9400 & 0.4000 & 3 & $\begin{array}{l}\text { Guofeng et al. } \\
(2012)\end{array}$ & brick stove (rural) & 1 \\
\hline
\end{tabular}




\begin{tabular}{|c|c|c|c|c|c|c|c|c|c|c|}
\hline willow & 0.2300 & 0.1000 & 0.4700 & 0.3000 & & & 3 & $\begin{array}{l}\text { Guofeng et al. } \\
(2012)\end{array}$ & brick stove (rural) & 1 \\
\hline $\begin{array}{l}\text { Paulownia tomen- } \\
\text { tosa }\end{array}$ & 0.3900 & 0.1200 & 0.9400 & 0.5100 & & & 3 & Guofeng et al. & brick stove (rural) & 1 \\
\hline toon & 0.1900 & 0.1300 & 0.5200 & 0.4100 & & & 3 & $\begin{array}{l}\text { Guofeng et al. } \\
(2012)\end{array}$ & brick stove (rural) & 1 \\
\hline white birch & 0.6900 & 0.3200 & 0.6700 & 0.6100 & & & 3 & $\begin{array}{l}\text { Guofeng et al. } \\
(2012)\end{array}$ & brick stove (rural) & 1 \\
\hline Lespedeza & 0.2100 & 0.1700 & 0.4800 & 0.4000 & & & 3 & Guofeng et al. & brick stove (rural) & 1 \\
\hline Buxus sinica & 1.2000 & 0.1000 & 2.5000 & 1.7000 & & & 3 & $\begin{array}{l}\text { Guofeng et al. } \\
(2012)\end{array}$ & brick stove (rural) & 1 \\
\hline holly & 0.7300 & 0.2800 & 1.6000 & 0.4000 & & & 3 & Guofeng et al. & brick stove (rural) & 1 \\
\hline bamboo & 0.1300 & 0.0900 & 1.2000 & 0.5000 & & & 3 & Guofeng et al. & brick stove (rural) & 1 \\
\hline barley straw & & & & & 0.0400 & 0.0000 & 2 & $\begin{array}{lr}\text { Jenkins } & \text { et al. } \\
(1996) ; & \text { a932- } \\
126 b \_1 & \end{array}$ & wind tunnel & 3 \\
\hline corn stover & & & & & 0.2000 & 0.0141 & 2 & $\begin{array}{l}\text { Jenkins et al. } \\
(1996) ; \\
126 b \_1\end{array}$ & wind tunnel & 3 \\
\hline rice straw & & & & & 0.5910 & 0.2150 & 8 & $\begin{array}{l}\text { Jenkins et al. } \\
(1996) ; \\
126 b \_1\end{array}$ & wind tunnel & 3 \\
\hline wheat straw & & & & & 0.4700 & 0.2758 & 2 & $\begin{array}{l}\text { Jenkins et al. } \\
(1996) ; \\
126 b \_1\end{array}$ & wind tunnel & 3 \\
\hline
\end{tabular}




\begin{tabular}{|c|c|c|c|c|c|c|c|c|c|c|}
\hline $\begin{array}{l}\text { seasoned oak } \\
\text { seasoned pine }\end{array}$ & & & & & $\begin{array}{l}0.1671 \\
0.2531\end{array}$ & 1 & $\begin{array}{l}\text { DeAngel } \\
(1980) \\
\text { DeAngel } \\
(1980\end{array}$ & $\begin{array}{l}\text { s et al. } \\
\text { s et al. }\end{array}$ & $\begin{array}{l}\text { nonbaffled stove } \\
\text { nonbaffled stove }\end{array}$ & 1 \\
\hline $\begin{array}{l}\text { Kentucky Blue- } \\
\text { grass }\end{array}$ & 15.0000 & 5.2000 & 0.5000 & 0.1100 & & 4 & $\begin{array}{l}\text { Holder } \\
(2017)\end{array}$ & et al. & field measurements, Aerostat & 4 \\
\hline $\begin{array}{l}\text { Kentucky Blue- } \\
\text { grass }\end{array}$ & 11.0000 & 6.1000 & 0.3200 & 0.1000 & & 4 & $\begin{array}{l}\text { Holder } \\
(2017)\end{array}$ & et al. & field measurements, ground & 4 \\
\hline $\begin{array}{l}\text { Kentucky Blue- } \\
\text { grass }\end{array}$ & & & 0.7600 & 0.3300 & & 4 & $\begin{array}{l}\text { Holder } \\
(2017)\end{array}$ & et al. & $\begin{array}{l}\text { field measurements, Aerostat, } \\
\text { eBC }\end{array}$ & 4 \\
\hline $\begin{array}{l}\text { Kentucky Blue- } \\
\text { grass }\end{array}$ & & & 0.9300 & 0.0730 & & 4 & $\begin{array}{l}\text { Holder } \\
(2017)\end{array}$ & et al. & $\begin{array}{l}\text { field measurements, ground, } \\
\text { eBC }\end{array}$ & 4 \\
\hline wheat & 9.4000 & 1.6000 & 0.5000 & 0.2000 & & 4 & $\begin{array}{l}\text { Holder } \\
(2017)\end{array}$ & et al. & field measurements, Aerostat & 3 \\
\hline wheat & 11.2000 & 2.5000 & 0.2000 & 0.0000 & & 4 & $\begin{array}{l}\text { Holder } \\
(2017)\end{array}$ & et al. & field measurements, ground & 3 \\
\hline wheat & & & 0.6000 & 0.1000 & & 4 & $\begin{array}{l}\text { Holder } \\
(2017)\end{array}$ & et al. & $\begin{array}{l}\text { field measurements, Aerostat, } \\
\mathrm{eBC}\end{array}$ & 3 \\
\hline wheat & & & 0.5000 & 0.1000 & & 4 & $\begin{array}{l}\text { Holder } \\
(2017)\end{array}$ & et al. & $\begin{array}{l}\text { field measurements, ground, } \\
\text { eBC }\end{array}$ & 3 \\
\hline wheat & & & 0.7000 & 0.0900 & & 8 & Zhang & et al. & $\begin{array}{l}\text { field measurements, EF based } \\
\text { on } \mathrm{CO}_{2}\end{array}$ & 3 \\
\hline rice & & & 0.5600 & 0.0400 & & 4 & $\begin{array}{l}\text { Zhang } \\
(2015)\end{array}$ & et al. & $\begin{array}{l}\text { field measurements, EF based } \\
\text { on } \mathrm{CO}_{2}\end{array}$ & 3 \\
\hline rapeseed & & & 2.8900 & 0.7000 & & 4 & $\begin{array}{l}\text { Zhang } \\
(2015)\end{array}$ & et al. & $\begin{array}{l}\text { field measurements, EF based } \\
\text { on } \mathrm{CO}_{2}\end{array}$ & 3 \\
\hline wheat & & & 0.4300 & 0.1000 & & 8 & $\begin{array}{l}\text { Zhang } \\
(2015)\end{array}$ & et al. & $\begin{array}{l}\text { field measurements, EF based } \\
\text { on } \mathrm{CO}\end{array}$ & 3 \\
\hline
\end{tabular}




\begin{tabular}{|c|c|c|c|c|c|c|c|c|c|c|}
\hline rapeseed & & & $\begin{array}{l}0.2500 \\
1.0100\end{array}$ & $\begin{array}{l}0.1100 \\
0.2700\end{array}$ & & & 4 & $\begin{array}{l}\text { Zhang } \\
(2015) \\
\text { Zhang } \\
(2015)\end{array}$ et al. & $\begin{array}{l}\text { field measurements, EF based } \\
\text { on CO } \\
\text { field measurements, EF based } \\
\text { on CO }\end{array}$ & 3 \\
\hline charcoal burning & 1.7800 & 2.8000 & 0.6500 & 0.3000 & & & 8 & Keita et al. (2018) & $\begin{array}{l}\text { trad. stoves (metal or baked } \\
\text { earth), field meas.; per } \mathrm{kg} \\
\text { charcoal }\end{array}$ & 5 \\
\hline charcoal making & 3.9300 & 1.0100 & 0.2200 & 0.1600 & & & 8 & Keita et al. (2018) & $\begin{array}{l}\text { trad. stoves (metal or baked } \\
\text { earth), field meas.; per } \mathrm{kg} \\
\text { wood }\end{array}$ & 6 \\
\hline wood (iroko) & 6.5000 & 1.9800 & 0.5200 & 0.3900 & & & 4 & Keita et al. 2018) & $\begin{array}{l}\text { traditional charcoal-making } \\
\text { furnaces, field meas. }\end{array}$ & 1 \\
\hline wood(hevea) & 15.6100 & 6.4400 & 1.4500 & 0.6100 & & & 4 & Keita et al. (2018) & $\begin{array}{l}\text { traditional charcoal-making } \\
\text { furnaces, field meas. }\end{array}$ & 1 \\
\hline charcoal making & & & & & 0.1860 & 0.1350 & 7 & Park et al. $(2013)$ & $\begin{array}{l}\text { charcoal kiln, field meas.; per } \\
\text { kg wood }\end{array}$ & 6 \\
\hline wheat stubble & 1.9000 & 1.0482 & & & & & 6 & $\begin{array}{l}\text { Dhammapala } \\
\text { et al. (2007a) }\end{array}$ & test burn facility & 3 \\
\hline $\begin{array}{l}\text { Kentucky Blue- } \\
\text { grass stubble }\end{array}$ & 6.9000 & 2.2346 & & & & & 29 & $\begin{array}{l}\text { Dhammapala } \\
\text { et al. }(2007 a)\end{array}$ & test burn facility & 4 \\
\hline wheat stubble & & & 0.3500 & 0.2382 & & & 11 & $\begin{array}{l}\text { Dhammapala } \\
\text { et al. (2007a) }\end{array}$ & test burn facility & 3 \\
\hline $\begin{array}{l}\text { Kentucky Blue- } \\
\text { grass stubble }\end{array}$ & & & 0.6300 & 0.1472 & & & 29 & $\begin{array}{l}\text { Dhammapala } \\
\text { et al. (2007a) }\end{array}$ & test burn facility & 4 \\
\hline wheat stubble & 2.7360 & 1.0080 & & & & & 4 & $\begin{array}{l}\text { Dhammapala } \\
\text { et al. }(2007 \mathrm{~b})\end{array}$ & field burning & 3 \\
\hline $\begin{array}{l}\text { Kentucky Blue- } \\
\text { grass stubble }\end{array}$ & 6.9330 & & & & & & 1 & $\begin{array}{l}\text { Dhammapala } \\
\text { et al. }(2007 \mathrm{~b})\end{array}$ & field burning & 4 \\
\hline
\end{tabular}




\begin{tabular}{|c|c|c|c|c|c|c|c|c|c|c|}
\hline $\begin{array}{l}\text { Kentucky Blue- } \\
\text { grass stubble }\end{array}$ & & & $\begin{array}{l}0.3760 \\
0.7980\end{array}$ & $\begin{array}{l}0.2890 \\
0.3440\end{array}$ & & & 2 & $\begin{array}{l}\text { Dhammapala } \\
\text { et al. }(2007 \mathrm{~b}) \\
\text { Dhammapala } \\
\text { et al. }(2007 \mathrm{~b})\end{array}$ & $\begin{array}{l}\text { field burning } \\
\text { field burning }\end{array}$ & 4 \\
\hline grass, ground & 7.0000 & & 0.6200 & & & & 1 & $\begin{array}{l}\text { Strand et al. } \\
(2016)\end{array}$ & ground & 4 \\
\hline grass, aerostat & 6.5000 & & 0.5600 & & & & 1 & $\begin{array}{l}\text { Strand et al. } \\
(2016)\end{array}$ & Aerostat & 4 \\
\hline grass, ground & & & 1.1000 & & & & 1 & $\begin{array}{l}\text { Strand et al. } \\
(2016)\end{array}$ & ground; continuous eBC & 4 \\
\hline grass, aerostat & & & 0.9100 & & & & 1 & $\begin{array}{l}\text { Strand et al. } \\
(2016)\end{array}$ & Aerostat; continuous eBC & 4 \\
\hline grass (Brazil) & 5.1000 & 2.2500 & 0.6500 & 0.4500 & 0.4400 & 0.1800 & 6 & Ferek et al. (1998) & airborne measurements & 4 \\
\hline fuel wood, Delhi & 0.8500 & 0.7000 & 0.3700 & 0.1800 & & & 101 & Saud et al. (2012) & dilution sampler & 1 \\
\hline fuel wood, Punjab & 0.9300 & 0.9600 & 0.4400 & 0.2900 & & & 139 & Saud et al. (2012) & dilution sampler & 1 \\
\hline $\begin{array}{l}\text { fuel wood, } \\
\text { Haryana }\end{array}$ & 0.7800 & 0.4100 & 0.4200 & 0.0700 & & & 92 & Saud et al. (2012) & dilution sampler & 1 \\
\hline $\begin{array}{l}\text { fuel wood, Uttar } \\
\text { Pradesh }\end{array}$ & 1.3200 & 1.0000 & 0.3100 & 0.1200 & & & 149 & Saud et al. (2012) & dilution sampler & 1 \\
\hline $\begin{array}{l}\text { fuel wood, Ut- } \\
\text { tarakhand }\end{array}$ & 0.9200 & 0.5400 & 0.2700 & 0.0800 & & & 181 & Saud et al. (2012) & dilution sampler & 1 \\
\hline fuel wood, Bihar & 1.2800 & 0.9900 & 0.3600 & 0.1900 & & & 85 & Saud et al. (2012) & dilution sampler & 1 \\
\hline $\begin{array}{l}\text { fuel wood, West } \\
\text { Bengal }\end{array}$ & 0.5500 & 0.7000 & 0.2500 & 0.1300 & & & 19 & Saud et al. (2012) & dilution sampler & 1 \\
\hline $\begin{array}{l}\text { crop residue, } \\
\text { Delhi }\end{array}$ & 2.1000 & 1.4400 & 0.5700 & 0.3600 & & & 20 & Saud et al. (2012) & dilution sampler & 2 \\
\hline $\begin{array}{l}\text { crop residue, } \\
\text { Punjab }\end{array}$ & 0.5600 & 0.2800 & 0.2500 & 0.0700 & & & 40 & Saud et al. (2012) & dilution sampler & 2 \\
\hline
\end{tabular}




\begin{tabular}{|c|c|c|c|c|c|c|c|c|}
\hline crop residue, & 0.9400 & 0.7100 & 0.4200 & 0.1300 & 35 & Saud et al. (2012) & dilution sampler & 2 \\
\hline Haryana & & & & & & & & \\
\hline $\begin{array}{l}\text { crop residue, Ut- } \\
\text { tar Pradesh }\end{array}$ & 2.3400 & 1.2800 & 0.3900 & 0.1900 & 107 & Saud et al. (2012) & dilution sampler & 2 \\
\hline $\begin{array}{l}\text { crop residue, } \mathrm{Bi}- \\
\text { har }\end{array}$ & 1.8700 & 1.6600 & 0.4300 & 0.5200 & 105 & Saud et al. (2012) & dilution sampler & 2 \\
\hline crop residue, & 0.9700 & 0.8800 & 0.1800 & 0.1100 & 20 & Saud et al. (2012) & dilution sampler & 2 \\
\hline West Bengal & & & & & & Soud ot ol (2012) & & \\
\hline dung cake, Delhi & 4.5100 & 1.3400 & 0.9000 & 0.3500 & 95 & Saud et al. (2012) & dilution sampler & 2 \\
\hline $\begin{array}{l}\text { dung cake, Pun- } \\
\text { jab }\end{array}$ & 4.6400 & 0.7800 & 0.5900 & 0.2400 & 48 & Saud et al. (2012) & dilution sampler & 2 \\
\hline dung cake, & 3.7800 & 0.4700 & 0.5400 & 0.3400 & 38 & Saud et al. (2012), & dilution sampler & 2 \\
\hline Haryana & & & & & & & & \\
\hline $\begin{array}{l}\text { dung cake, Uttar } \\
\text { Pradesh }\end{array}$ & 4.4100 & 1.1900 & 0.4100 & 0.2100 & 45 & Saud et al. (2012) & dilution sampler & 2 \\
\hline dung cake, Bihar & 4.1400 & 1.4800 & 0.2800 & 0.2100 & 68 & Saud et al. (2012) & dilution sampler & 2 \\
\hline $\begin{array}{l}\text { dung cake, West } \\
\text { Bengal }\end{array}$ & 1.7400 & 1.1000 & 0.2200 & 0.1300 & 8 & Saud et al. (2012) & dilution sampler & 2 \\
\hline rice straw & 2.7838 & 1.1874 & 0.4789 & 0.2891 & 4 & Oanh et al. (2011) & field burning & 3 \\
\hline wheat straw & 2.6000 & 1.8000 & 0.4600 & 0.1900 & 3 & Wei et al. $(2014)$ & $\begin{array}{l}\text { improved two-pot stove with } \\
\text { chimney, 1-year old }\end{array}$ & 2 \\
\hline rape straw & 0.5800 & 0.1700 & 0.4700 & 0.4800 & 3 & Wei et al. (2014) & $\begin{array}{l}\text { improved two-pot stove with } \\
\text { chimney, 1-year old }\end{array}$ & 2 \\
\hline rice straw & 1.1000 & 0.9000 & 0.5100 & 0.3700 & 3 & Wei et al. (2014) & $\begin{array}{l}\text { improved two-pot stove with } \\
\text { chimney, 1-year old }\end{array}$ & 2 \\
\hline cotton straw & 3.1000 & 4.5000 & 1.2000 & 1.4000 & 3 & Wei et al. (2014) & $\begin{array}{l}\text { improved two-pot stove with } \\
\text { chimney, 1-year old }\end{array}$ & 2 \\
\hline wheat straw & 4.1000 & 1.8000 & 1.4000 & 0.9000 & 3 & Wei et al. (2014) & $\begin{array}{l}\text { improved two-pot stove with } \\
\text { chimney, } 15 \text {-year old }\end{array}$ & 2 \\
\hline
\end{tabular}




\begin{tabular}{|c|c|c|c|c|c|c|c|c|c|c|}
\hline rape straw & 4.9000 & 6.5000 & 2.7000 & 2.4000 & & & 3 & Wei et al. (2014) & improved two-pot stove with & 2 \\
\hline rice straw & 1.5000 & 0.6000 & 0.6400 & 0.1900 & & & 3 & Wei et al. (2014) & improved two-pot stove with & 2 \\
\hline cotton straw & 2.5000 & 1.8000 & 0.9600 & 0.9000 & & & 3 & Wei et al. (2014) & $\begin{array}{l}\text { improved two-pot stove with } \\
\text { chimney, } 15 \text {-year old }\end{array}$ & 2 \\
\hline wheat straw & 4.0659 & 0.3297 & 0.3187 & 0.0220 & & & 3 & Tian et al. (2017) & traditional stove & 2 \\
\hline maize straw & 7.0330 & 1.9780 & 0.5275 & 0.0769 & & & 3 & Tian et al. (2017) & traditional stove & 2 \\
\hline rice straw & 8.4615 & 1.4286 & 0.5714 & 0.0659 & & & 3 & Tian et al. (2017) & traditional stove & 2 \\
\hline charcoal burning & & & & & 0.5000 & 0.3000 & 1 & Gadi et al. $(2011)$ & U-shaped chimney & 5 \\
\hline
\end{tabular}




\section{References}

Aalde, H., P. Gonzalez, M. Gytarsky, T. Krug, A. Kurz W, D. Lasco R, L. Martino D, G. McConkey B, M. Ogle S, K. Paustian, J. Raison, H. Ravindranath N, D. Schoene, P. Smith, Z. Somogyi, A. A. van, and L. Verchot (2006). "Generic methodologies applicable to multiple land-use categories". In: 2006 IPCC Guidelines for National Greenhouse Gas Inventories. Volume 4: Agriculture, Forestry and Other Land Use. Chap. 2.

AIRUSE LIFE (2016). Emission factors for biomass burning, Report 9. Tech. rep. AIRUSE LIFE $11 \mathrm{ENV} / \mathrm{ES} / 584$.

Alves, C., C. Gonçalves, A. P. Fernandes, L. Tarelho, and C. Pio (2011). "Fireplace and woodstove fine particle emissions from combustion of western Mediterranean wood types". In: Atmos. Res. 101.3. International Conference on Nucleation and Atmospheric Aerosols (Part 2), pp. 692-700. ISSN: 0169-8095. DOI: https://doi.org/10.1016/j.atmosres.2011.04.015. URL: http://www.sciencedirect.com/science/article/pii/S0169809511001268.

Arora, V. K. and J. R. Melton (Apr. 2018). "Reduction in global area burned and wildfire emissions since 1930s enhances carbon uptake by land". In: Nat. Commun. 9.1, pp. 13261326. ISSN: 2041-1723. URL: https://www.ncbi.nlm.nih.gov/pubmed/29666366.

Bader, J., J. Jungclaus, N. Krivova, S. Lorenz, A. Maycock, T. Raddatz, H. Schmidt, M. Toohey, C.-J. Wu, and M. Claussen (2019, in review). "Global temperature modes shed light on the Hologene temperature conundrum". In: Nat. Commun.

Bond, T. C., D. G. Streets, K. F. Yarber, S. M. Nelson, J.-H. Woo, and Z. Klimont (2004). "A technology-based global inventory of black and organic carbon emissions from combustion". In: Journal of Geophysical Research: Atmospheres 109.D14. DOI: 10.1029/2003JD003697. eprint: https://agupubs . onlinelibrary . wiley . com/doi/pdf/10.1029/2003JD003697. URL: https://agupubs .onlinelibrary.wiley.com/doi/abs/10.1029/2003JD003697.

Calvo, A., V. Martins, T. Nunes, M. Duarte, R. Hillamo, K. Teinilä, V. Pont, A. Castro, R. Fraile, L. Tarelho, and C. Alves (2015). "Residential wood combustion in two domestic devices: Relationship of different parameters throughout the combustion cycle". In: Atmos. Environ. 116, pp. 72-82. ISSN: 1352-2310. DOI: https://doi.org/10.1016/j . atmosenv . 2015.06. 012. URL: http://wWw.sciencedirect.com/science/article/pii/S1352231015301552.

Cao, G., X. Zhang, S. Gong, and F. Zheng (2008). "Investigation on emission factors of particulate matter and gaseous pollutants from crop residue burning". In: J. Environ. Sci. 20, pp. $50-55$.

Cruz, M. G., A. L. Sullivan, R. J. Hurley, M. P. Plucinski, and J. S. Gould (2017). The effect of fuel load and structure on grassland fire behaviour and fire danger. Tech. rep. CSIRO Land and Water, Client Report No EF178976, Canberra, Australia.

Cruz, M. G., A. S. Sullivan, S. Kidnie, R. Hurley, and S. Nichols (2016). The effect of grass curing and fuel structure on fire behaviour. Final report. Tech. rep. CSIRP Land and Water, Client Report No EP 166414, Canberra, Australia.

DeAngelis, D. G., D. S. Ruffin, and R. B. Reznik (1980). Preliminary Characterization of Emissions from Wood-fired Resiential Combustion Equipment. U.S. Environmental Protection Agency, EPA-600/7-80-040.

Dhammapala, R., C. Claiborn, J. Jimenez, J. Corkill, B. Gullett, C. Simpson, and M. Paulsen (2007a). "Emission factors of PAHs, methoxyphenols, levoglucosan, elemental carbon and organic carbon from simulated wheat and Kentucky bluegrass stubble burns". In: Atmos. Environ. 41, pp. 2660-2669. 
Dhammapala, R., C. Claiborn, C. Simpson, and J. Jimenez (2007b). "Emission factors from wheat and Kentucky bluegrass stubble burning: Comparison of field and simulated burn experiments". In: Atmos. Environ. 41, pp. 1512-1520.

Dimitrakopoulos, A. P. (2002). "Mediterranean fuel models and potential fire behaviour in Greece". In: International Journal of Wildland Fire 11, pp. 127-130. DOI: 10.1071/WF02018.

Dyer, R. M. (2011). "Fire and Vegetation Management in Pasture Lands of the Victoria River District, Northern Territory". MA thesis. School, Land, and Food Sciences, The University of Queensland.

Ferek, R. J., J. S. Reid, P. V. Hobbs, D. R. Blake, and C. Liousse (1998). "Emission factors of hydrocarbons, halocarbons, trace gases and particles from biomass burning in Brazil". In: $J$. Geophys. Res. 103.D24, pp. 32107-32118.

Fernandes, A. P., C. Alves, C. Gonçalves, L. Tarelho, C. Pio, C. Schimdl, and H. Bauer (2011). "Emission factors from residential combustion appliances burning Portuguese biomass fuels". In: J. Environ. Monit. 11, pp. 3196-3206. DOI: 10.1039/c1em10500k.

Frost, P. G. H. and F. Robertson (1987). "Chapter 5 - Fire. The ecological effects of fire in savannas. presentations made by savanna researchers at a workshop in Harare, Zimbabwe, December 1985". In: Walker, B. H. Determinants of tropical savannas. IUBS monograph series no.3.

Gadi, R., U. C. Kulshrestha, A. K. Sarkar, S. C. Garg, and D. C. Parashar (2011). "Emissions of $\mathrm{SO}_{2}$ and $\mathrm{NO}_{x}$ from biofuels in India". In: Tellus B: Chemical and Physical Meteorology 55.5, pp. 787-795. DOI: 10.3402/tellusb.v55i3.16370.

Goodchild, H. (2007). "Modelling Roman agricultural production in the middle Tiber Valley, Central Italy". PhD thesis. Institute of Archaeology and Antiquity, School of Historical Studies, The University of Birmingham.

Guofeng, S., W. Siye, W. Wen, Z. Yanyan, M. Yujia, W. Bin, W. Rong, L. Wei, S. Huizhong, H. Ye, Y. Yifeng, W. Wei, W. Xilong, W. Xuejun, and T. Shu (Apr. 2012). "Emission Factors, Size Distributions, and Emission Inventories of Carbonaceous Particulate Matter from Residential Wood Combustion in Rural China". In: Environ. Sci. Technol. 46.7, pp. 4207-4214. ISSN: 0013-936X. DOI: 10.1021/es203957u. URL: https://doi.org/10.1021/es203957u.

Habib, G., C. Venkataraman, T. C. Bond, and J. J. Schauer (2008). "Chemical, Microphysical and Optical Properties of Primary Particles from the Combustion of Biomass Fuels". In: Environ. Sci. Technol. 42, pp. 8829-8834.

Haider, M. Z. (2011). Economics of Rice Residue Burning in the South-West Region of Bangladesh. Final Report. Tech. rep. Economic Research Group, Dhaka, Bangladesh.

Hamilton, D., S. Hantson, C. Scott, J. Kaplan, K. Pringle, L. Nieradzik, A. Rap, G. Folberth, D. Spracklen, and K. Carslaw (Dec. 2018). "Reassessment of pre-industrial fire emissions strongly affects anthropogenic aerosol forcing". English. In: Nat. Commun. 9.1. ISSN: 20411723. DOI: $10.1038 / \mathrm{s} 41467-018-05592-9$.

Harris, W. (2013). "Defining and Detecting Mediterranean Deforestation, 800BCE to 700CE". In: The Ancient Mediterranean Environment between Science and History. Leiden, The Netherlands: Brill, pp. 173-194. ISBN: 9789004254053. URL: https : //brill .com/view/ book/edcoll/9789004254053/B9789004254053_008.xml.

Hays, M. D., P. M. Fine, C. D. Geron, M. J. Kleeman, and B. K. Gullett (2005). "Open burning of agricultural biomass: Physical and chemical properties of particle-phase emissions". In: Atmos. Environ. 39, pp. 6747-6764.

Holder, A., B. Gullett, S. Urbanski, R. Elleman, S. O'Neill, D. Tabor, W. Mitchell, and K. Baker (2017). "Emissions from prescribed burning of agricultural fields in the Pacific Northwest". 
In: Atmos. Environ. 166, pp. 22-33. ISSN: 1352-2310. DOI: https://doi.org/10.1016/j . atmosenv.2017.06.043. URL: http://www.sciencedirect.com/science/article/pii/ S1352231017304247.

Hopkins, K. (2017). "Models, Ships and Staples". In: Sociological Studies in Roman History. Ed. by C. Kelly. Cambridge Classical Studies. Cambridge University Press, pp. 213-268. DOI: 10.1017/CB09781139093552.009.

Jenkins, B. M., S. Q. Turn, R. B. Williams, M. Goronea, H. Abd-el-Fattah, J. Mehlschau, N. Raubach, D. P. Y. Chang, M. Kang, S. V. Teague, O. G. Raabe, D. E. Campbell, T. A. Cahill, L. Pritchett, J. Chow, and A. D. Jones (1996). Atmospheric Pollutant Emission Factors From Open Burning of Agricultural and Forest Biomass by Wind Tunnel Simulations: Volume 1-3. Research rep. California Environmental Protection Agency, contract NO. A932-126.

Jimenez, J. R., C. S. Claiborn, R. S. Dhammapala, and C. D. Simpson (2007). "Methoxyphenols and Levoglucosan Ratios in PM2.5 from Wheat and Kentucky Bluegrass Stubble Burning in Eastern Washington and Northern Idaho". In: Environ. Sci. Technol. 41, pp. 7824-7829.

Keita, S., C. Liousse, V. Yoboué, P. Dominutti, B. Guinot, E.-M. Assamoi, A. Borbon, S. L. Haslett, L. Bouvier, A. Colomb, H. Coe, A. Akpo, J. Adon, J. Bahino, M. Doumbia, J. Djossou, C. Galy-Lacaux, E. Gardrat, S. Gnamien, J. F. Léon, M. Ossohou, E. T. N'Datchoh, and L. Roblou (2018). "Particle and VOC emission factor measurements for anthropogenic sources in West Africa". In: Atmos. Chem. Phys. 18.10, pp. 7691-7708. DoI: 10.5194/acp18-7691-2018. URL: https://www . atmos-chem-phys .net/18/7691/2018/.

Lamarque, J.-F., T. C. Bond, V. Eyring, C. Granier, A. Heil, Z. Klimont, D. Lee, C. Liousse, A. Mieville, B. Owen, M. G. Schultz, D. Shindell, S. J. Smith, E. Stehfest, J. Van Aardenne, O. R. Cooper, M. Kainuma, N. Mahowald, J. R. McConnell, V. Naik, K. Riahi, and D. P. van Vuuren (2010). "Historical (1850-2000) gridded anthropogenic and biomass burning emissions of reactive gases and aerosols: methodology and application". In: Atmos. Chem. Phys. 10.15, pp. 7017-7039. DOI: 10.5194/acp-10-7017-2010.

Lasslop, G., K. Thonicke, and S. Kloster (2014). "SPITFIRE within the MPI Earth system model: Model development and evaluation". In: J. Adv. Model. Earth Syst. 6, pp. 740-755. DOI: $10.1002 / 2013 M S 000284$.

Li, C., Y. Hu, F. Zhang, J. Chen, Z. Ma, X. Ye, X. Yang, L. Wang, X. Tang, R. Zhang, M. Mu, G. Wang, H. Kan, X. Wang, and A. Mellouki. (2017). "Multi-pollutant emissions from the burning of major agricultural residues in China and the related health-economic effects". In: Atmos. Chem. Phys. 17, pp. 4957-4988.

Li, J., Y. Bo, and S. Xie (2016a). "Estimating emissions from crop residue open burning in China based on statistics and MODIS fire products". In: J. Environ. Sci. 44, pp. 158-170. ISSN: 1001-0742. DOI: https ://doi.org/10.1016/j·jes .2015.08.024 URL: http: //www.sciencedirect.com/science/article/pii/S1001074216000061.

Li, J., Y. Li, Y. Bo, and S. Xie (2016b). "High-resolution historical emission inventories of crop residue burning in fields in China for the period 1990-2013". In: Atmos. Environ. 138, pp. 152-161. ISSN: 1352-2310. DOI: https://doi.org/10.1016/j .atmosenv.2016.05.002. URL: http://www.sciencedirect.com/science/article/pii/S135223101630334X.

Little, I. T., P. A. Hockey, and R. Jansen (2015). "Impacts of fire and grazing management on South Africa's moist highland grasslands: A case study of the Steenkampsberg Plateau, Mpumalanga, South Africa". en. In: Bothalia - African Biodiversity $\&$ Conservation 45, pp. 1-15. ISSN: 0006-8241. URL: http://www.scielo.org.za/scielo.php?script=sci_ arttext\&pid=S0006-82412015000100006\&nrm=iso 
Lohri, C. R., H. M. Rajabu, D. J. Sweeney, and C. Zurbrügg (2016). "Char fuel production in developing countries - A review of urban biowaste carbonization". In: Renewable Sustainable Energy Rev. 59, pp. 1514-1530. ISSN: 1364-0321. DOI: https:// doi .org/10.1016/ j . rser.2016.01.088. URL: http://www.sciencedirect.com/science/article/pii/ S1364032116001180.

Magi, B. I. (2015). "Global Lightning Parameterization from CMIP5 Climate Model Output". In: J. Atmos. Oceanic Technol. 32.3, pp. 434-452. DOI: 10.1175/JTECH-D-13-00261.1.

McDonald, J. D., B. Zielinska, E. M. Fujita, J. C. Sagebiel, J. C. Chow, and J. G. Watson (2000). "Fine Particle and Gaseous Emission Rates from Residential Wood Combustion". In: Environmental Science $\&$ Technology 34.11, pp. 2080-2091. DOI: 10.1021/es9909632 eprint: https://doi.org/10.1021/es9909632. URL: https://doi.org/10.1021/es9909632.

Mietz, M. (2016). "The fuel economy of public bathhouses in the Roman Empire". MA thesis. Faculty of Arts and Philosophy, Campus Boekentoren, Blandijnberg 2, B-9000 Ghent, Belgium: Ghent University.

Montiel, C. and D. Kraus (2010). Best Practices of Fire Use - Prescribed Burning and Suppression Fire Programmes in Selected Case-Study Regions of Europe. Research Report 24. Research rep. European Forest Institute.

Norman, M. J. T. (1963). "The short term effects of time and frequency of burning on native pastures at Katherine, N. T." In: Australian Journal of Experimental Agriculture and Animal Husbandry 3, pp. 26-29.

- (1969). "The effect of burning and seasonal rainfall on native pasture at Katherine, N. T." In: Australian Journal of Experimental Agriculture and Animal Husbandry 9, pp. 295-298.

Oanh, N. T. K., B. T. Ly, D. Tipayarom, B. R. Manandhar, P. Prapat, C. D. Simpson, and L.-J. S. Liu (2011). "Characterization of particulate matter emission from open burning of rice straw". In: Atmos. Environ. 45, pp. 493-502.

Olson, S. D. (1991). "Firewood and charcoal in Classical Athens". In: Hesperia: The Journal of the American of Classical Studies at Athens 60.3, pp. 411-420.

Oluwole, F. A., J. M. Sambo, and D. Sikhalazo (2008). "Long-term effects of different burning frequencies on the dry savannah grassland in South Africa". In: African Journal of Agricultural Research 3.2, pp. 147-153.

Pandey, A., S. Patel, S. Pervez, S. Tiwari, G. Yadama, J. C. Chow, J. G. Watson, P. Biswas, and R. K. Chakrabarty (2017). "Aerosol emissions factors from traditional biomass cookstoves in India: insights from field measurements". In: Atmos. Chem. Phys. 17, pp. 13721-13729.

Papanastasis, V. P. (1980). "Effects of Season and Frequency of Burning on a Phryganic Rangeland in Greece". In: Journal of Range Management 33.4, pp. 251-255.

Park, S.-K., S.-J. Choi, J.-Y. Kim, G.-J. Park, U.-H. Hwang, J.-J. Lee, and T.-S. Kim (2013). "A Field Survey on the Characteristics of Air Pollutants Emission from Commercial Charcoal Kiln". In: J. Kosae 29.5, pp. 601-614.

Pfeiffer, M., A. Spessa, and J. O. Kaplan (2013). "A model for global biomass burning in preindustrial time: LPJ-LMfire (v1.0)". In: Geosci. Model Dev. 6.3, pp. 643-685. DOI: 10. 5194/gmd-6-643-2013. URL: https://www.geosci-model-dev.net/6/643/2013/.

PRSC (2015). Monitoring Residue Burning through Satellite Remote Sensing. submitted to: Punjab Pollution Control Board, Patiala - 147001. Tech. rep. Punjab Remote Sensing Centre. Ludhiana - 141004.

Rabin, S. S., J. R. Melton, G. Lasslop, D. Bachelet, M. Forrest, S. Hantson, J. O. Kaplan, F. Li, S. Mangeon, D. S. Ward, C. Yue, V. K. Arora, T. Hickler, S. Kloster, W. Knorr, L. Nieradzik, A. Spessa, G. A. Folberth, T. Sheehan, A. Voulgarakis, D. I. Kelley, I. C. Prentice, 
S. Sitch, S. Harrison, and A. Arneth (2017). "The Fire Modeling Intercomparison Project (FireMIP), phase 1: experimental and analytical protocols with detailed model descriptions". In: Geosci. Model Dev. 10.3, pp. 1175-1197. DOI: 10.5194/gmd-10-1175-2017, URL: https: //www.geosci-model-dev.net/10/1175/2017//

Rowan, E. (2015). "Olive oil pressing waste as a fuel source in Antiquity". In: American Journal of Archaeology 119.4, pp. 465-482. DOI: 10.3764/aja.119.4.0465.

Sahai, S., C. Sharma, D. P. Singh, C. K. Dixit, N. Singh, P. Sharma, K. Singh, S. Bhatt, S. Ghude, V. Gupta, R. K. Gupta, M. K. Tiwari, S. C. Garg, A. P. Mitra, and P. K. Gupta (2007). "A study for development of emission factors for trace gases and carbonaceous particulate species from in situ burning of wheat straw in agricultural fields in india”. In: Atmos. Environ. 41, pp. 9173-9186.

SANBI (2014). Grazing and Burning Guidelines: Managing Grasslands for Biodiversity and Livestock Production. Compiled by Lechmere-Oertel, $R$. G. Research rep. South African National Biodiversity Institute, Pretoria.

Saud, T., R. Gautam, T. K. Mandal, S. Gadi R., S. D. P., S. K., M. Dahiya, and M. Saxena (2012). "Emission estimates of organic and elemental carbon from household biomass fuel used over the Indo-Gangetic Plain (IGP), India". In: Atmos. Environ. 61, pp. 212-220.

Shea, R. W., B. W. Shea, J. B. Kauffman, D. E. Ward, C. I. Haskins, and M. C. Scholes (1996). "Fuel biomass and combustion factors associated with fires in savanna ecosystems of South Africa and Zambia". In: J. Geophys. Res. 101.D19, pp. 23551-23568.

Shen, G., Y. Yang, W. Wang, S. Tao, C. Zhu, Y. Min, M. Xue, J. Ding, B. Wang, R. Wang, H. Shen, W. Li, X. Wang, and A. G. Russell (Sept. 2010). "Emission Factors of Particulate Matter and Elemental Carbon for Crop Residues and Coals Burned in Typical Household Stoves in China". In: Environ. Sci. Technol. 44.18, pp. 7157-7162. ISSN: 0013-936X. DOI: 10.1021/es101313y, URL: https://doi.org/10.1021/es101313y

Sinclair, T. R. (1998). "Historical Changes in Harvest Index and Crop Nitrogen Accumulation. Review and Interpretation". In: Crop Sci. 38.3.

Smith, K. R. (2000). Greenhouse gases from small-scale combustion devices in developing countries Phase IIa. Household Stoves in India. Tech. rep. U.S. Environmental Protection Agency.

Smith, M. D., B. W. van Wilgen, C. E. Burns, N. Govender, A. L. F. Potgieter, S. Andelman, H. C. Biggs, J. Botha, and W. S. W. Trollope (2013). "Long-term effects of fire frequency and season on herbaceous vegetation in savannas of the Kruger National Park, South Africa". In: Journal of Plant Ecology 6.1, pp. 71-83. DOI: 10.1093/jpe/rts014. eprint: /oup/ backfile/content_public/journal/jpe/6/1/10.1093_jpe_rts014/1/rts014.pdf. URL: http://dx.doi.org/10.1093/jpe/rts014

Spurr, M. S. (1986). Arable cultivation in Roman Italy. c.200 B.C.-c.A.D. 100. 31-34 Gordon Square, London WC1H 0PP: The Society for the Promotion of Roman Studies.

Strand, T., B. Gullett, S. Urbanski, S. O’Neill, B. Potter, J. Aurell, A. Holder, N. Larkin, M. Moore, and M. Rorig (2016). "Grassland and forest understorey biomass emissions from prescribed fires in the southeastern United States - RxCADRE 2012". In: 25, pp. 102-113.

Tataryn (2016). The Roman Empire and its clients in 117 AD during the reign of emperor Trajan. Ed. by Wikimedia Commons, retrieved 14 Nov 2018. uRL: https://commons .wikimedia. org/wiki/File:Roman_Empire_Trajan_117AD.png.

Temin, P. (2006). "The Economy of the Early Roman Empire". In: J. Econ. Perspect. 20.1, pp. $133-151$.

Tian, J., H. Ni, J. Cao, Y. Han, Q. Wang, X. Wang, L.-W. Chen, J. C. Chow, J. G. Watson, C. Wei, J. Sun, T. Zhang, and R. Huang (2017). "Characteristics of carbonaceous particles 
from residential coal combustion and agricultural biomass burning in China". In: Atmospheric Pollution Research 8.3, pp. 521-527. ISSN: 1309-1042. DOI: https ://doi.org/10.1016/ j.apr.2016.12.006. URL: http://www. sciencedirect.com/science/article/pii/ S1309104216302896.

Turn, S. Q., B. M. Jenkins, J. C. Chow, L. C. Pritchett, D. Campbell, T. Cahill, and S. A. Whalen (1997). "Elemental characterizationof particulate matter emitted from biomass burning: Wind tunnel derived source profiles for herbaceous and wood fuels". In: J. Geophys. Res. 102.D3, pp. 3683-3699.

Van Marle, M. J. E., S. Kloster, B. I. Magi, J. R. Marlon, A.-L. Daniau, R. D. Field, A. Arneth, M. Forrest, S. Hantson, N. M. Kehrwald, W. Knorr, G. Lasslop, F. Li, S. Mangeon, C. Yue, J. W. Kaiser, and G. R. van der Werf (2017). "Historic global biomass burning emissions for CMIP6 (BB4CMIP) based on merging satellite observations with proxies and fire models (1750-2015)". In: Geosci. Model Dev. 10.9, pp. 3329-3357. Dor: 10.5194/gmd-10-33292017. URL: https://www.geosci-model-dev.net/10/3329/2017//

Veal, R. (2017). "Wood and Charcoal for Rome: Towards an Understanding of Ancient Regional Fuel Economics". In: The Economic Integration of Roman Italy. Leiden, The Netherlands: Brill, pp. 388-406. ISBN: 9789004345027. URL: https://brill.com/view/book/edcoll/ 9789004345027/B9789004345027_017.xml.

Wei, S., G. Shen, Y. Zhang, M. Xue, H. Xie, P. Lin, Y. Chen, X. Wang, and S. Tao (2014). "Field measurement on the emissions of PM, OC, EC and PAHs from indoor crop straw burning in rural China”. In: Environ. Pollut. 184, pp. 18-24. IssN: 0269-7491. DOI: https: //doi.org/10.1016/j.envpol.2013.07.036. URL: http://www .sciencedirect.com/ science/article/pii/S0269749113004120.

Weir, J. R., S. D. Fuhlendorf, D. M. Engle, T. G. Bidwell, D. C. Cummings, D. Elmore, R. F. Limb, B. W. Allred, J. D. Scasta, and S. L. Winter (2013). Patch Burning: Integrating Fire and Grazing to Promote Heterogeneity. Tech. rep. Department of Natural Resource Ecology and Management, Oklahoma Cooperative Extension Service.

Wood, T. S. and S. Baldwin (1985). "Fuelwood and charcoal use in developing countries". In: Ann. Rev. Energy 10, pp. 407-429.

Yang, S., H. He, S. Lu, D. Chen, and J. Zhu (2008). "Quantification of crop residue burning in the field and its influence on ambient air quality in Suqian, China". In: Atmos. Environ. 42.9, pp. 1961-1969. ISSN: 1352-2310. DOI: https://doi.org/10.1016/j.atmosenv.2007.12. 007. URL: http://www.sciencedirect.com/science/article/pii/S1352231007011326.

Yevich, R. and J. A. Logan (2003). "An assessment of biofuel use and burning of agricultural waste in the developing world". In: Global Biogeochem. Cycles 17.4. DOI: $10.1029 /$ 2002 GB001952

Zhang, J., K. Smith, Y. Ma, S. Ye, F. Jiang, W. Qi, P. Liu, M. Khalil, R. Rasmussen, and S. Thorneloe (2000). "Greenhouse gases and other airborne pollutants from household stoves in China: a database for emission factors". In: Atmos. Environ. 34.26, pp. 4537-4549. ISSN: 1352-2310. DOI: https : // doi . org/10 .1016/S1352-2310(99) 00450-1. URL: http : //www.sciencedirect.com/science/article/pii/S1352231099004501.

Zhang, T., M. J. Wooster, D. C. Green, and B. Main (2015). "New field-based agricultural biomass burning trace gas, PM2.5, and black carbon emission ratios and factors measured in situ at crop residue fires in Eastern China". In: Atmos. Environ. 121. Interdisciplinary Research Aspects of Open Biomass Burning and its Impact on the Atmosphere, pp. 2234. ISSN: 1352-2310. DOI: https://doi .org/10.1016/j . atmosenv . 2015.05.010. URL: http://www.sciencedirect.com/science/article/pii/S1352231015300807. 